\title{
Análise multitemporal da expansão urbana de Maringá-PR durante o período de 1947 a 2014 envolvendo o Parque Municipal do Cinquentenário e as principais áreas verdes do município
}

\author{
Multitemporal analysis of urban expansion Maringá - PR during the period 1947 to 2014 \\ involving the Park City of Fiftieth and main green áreas of the city
}

\author{
Felipe Gomes Rubira \\ Mestre em Geografia (UEM) - Doutorando em Geografia pela \\ Universidade Estadual de Campinas (UNICAMP) \\ felipe_rubira@hotmail.com
}

\section{Resumo}

Artigo recebido para revisão em 04/09/2015 e aceito para publicação em 17/12/2015

A hipótese desta pesquisa surge através da premissa de que a maioria das áreas verdes localizadas em municípios brasileiros acabam sendo alteradas negativamente pelo processo de expansão urbana e pelo aumento populacional. O objetivo da pesquisa é realizar uma análise multitemporal da expansão urbana relacionada com o aumento populacional de Maringá-PR que influenciaram na mudança da paisagem das áreas verdes do município, caracterizando por meio de períodos estabelecidos em décadas como foi sendo materializada a expansão da malha urbana em direção as áreas verdes. Concluiu-se que a urbanização acelerada do município começou a envolver as áreas verdes da cidade em todas as direções e os primeiros processos de degradação ambiental começaram a surgir, restando pequenas manchas de mata nativa. Verificou-se que os principais problemas ambientais do Parque Municipal do Cinquentenário coincidem com a aproximação da urbanização no entorno deles, em suas áreas limítrofes. Concluiu-se também, que a metodologia aplicada da análise multitemporal, mostrou-se eficiente quanto às avaliações temporais urbanas e ambientais, tornando-se ferramenta útil para um futuro plano de gestão ambiental dos órgãos governamentais responsáveis.

Palavras-Chave: Análise multitemporal, expansão urbana, aumento populacional, degradação ambiental, áreas verdes.

\begin{abstract}
The hypothesis of this research comes from the premise that the majority of green areas located in municipalities end up being changed negatively by the process of urban expansion and population increase. The objective of the research is to conduct a multi-temporal analysis of urban expansion related to the population increase of Maringa-PR that influenced the landscape change from green areas of the city, featuring through periods established for decades as it was being materialized the expansion of the urban fabric toward the green areas. It was concluded that the rapid urbanization of the city began to engage the green areas of the city in all directions and the first environmental degradation processes began to emerge, leaving small patches of native forest. It was found that the main environmental problems of the Cinquantenaire Park Municipal coincide with the approach of urbanization in their environment, in their neighboring areas. It was also concluded that the methodology applied in the multi-temporal analysis, proved efficient as to urban and environmental temporal ratings, becoming a useful tool for future environmental management plan of the responsible government agencies.
\end{abstract}

Keywords: Multitemporal analysis, urban expansion, population increase, environmental degradation, green áreas. 


\section{INTRODUÇÃO}

Atualmente percebemos a importância que as áreas que possuem remanescentes de cobertura vegetal exercem em relação à manutenção e o equilíbrio do meio ambiente, como a proteção contra o assoreamento dos cursos d'água, proteção dos solos quanto à erosão, regularização dos regimes hídricos, dentre outros fatores.

O que torna essas áreas ainda mais importantes para a preservação e conservação é o fato de sua existência ser rara atualmente na maioria dos municípios brasileiros, isso devido ao desenvolvimento econômico do homem, materializado e evidenciado em uma rápida urbanização, muitas vezes desenfreada, principalmente em grandes centros populacionais, as chamadas metrópoles.

A cidade de Maringá, Estado do Paraná, não foge desta regra, é uma cidade com 68 anos completados em 2015, foi fundada em 1947 e teve um crescimento vertiginoso durante as últimas décadas, tanto que já conta com 357.077 habitantes de acordo com o último censo realizado pelo Instituto Brasileiro de Geografia (IBGE, 2010).

A cidade de Maringá possui áreas de remanescentes florestais como o Parque Municipal do Cinquentenário, Parque do Ingá, Bosque II, Horto Florestal, entre outros que são considerados unidades de conservação, no entanto, apenas uma pequena porção dessas matas nativas se tornaram áreas de proteção ambiental em Maringá, por meio da Lei № 9.985, de 18 de Julho de 2000 que instituiu o Sistema Nacional de Unidades de Conservação da Natureza - SNUC, Brasil (2000).

Quando essas áreas de conservação estão inseridas em ambientes urbanos, como é o caso do Parque Municipal do Cinquentenário e das demais áreas verdes do município, percebe-se uma nítida alteração em seu estado original, o processo de urbanização produz impactos ambientais negativos originando inúmeros casos de degradação ambiental.

A hipótese desta pesquisa surge através da premissa de que a maiorias das áreas verdes protegidas localizadas em municípios brasileiros acabam sendo afetadas, alteradas pelo processo de expansão urbana e pelo aumento populacional, surgindo alguns casos de degradação ambiental provenientes do desenvolvimento sem medida que envolve essas áreas verdes.

Desta maneira, será evidenciado como a urbanização se aproximou e envolveu essas áreas em um curto período de tempo, tendo como exemplo a malha urbana do município de Maringá PR, que envolveu o Parque Municipal do Cinquentenário e as demais áreas verdes do município diretamente protegidas pela Prefeitura Municipal de Maringá (PMM), em apenas 68 anos, gerando uma pressão antrópica nesses parques urbanos.

Portanto, esta pesquisa tem como objetivo principal, realizar uma análise multitemporal da expansão urbana de Maringá relacionada com o aumento populacional do município, que 
influenciaram na mudança da paisagem do Parque Municipal do Cinquentenário e das demais áreas verdes do espaço urbano, caracterizando por meio de períodos estabelecidos em décadas como foi sendo materializada a expansão da malha urbana em direção as áreas verdes protegidas.

\section{METODOLOGIA}

Nesta parte descrevem-se os procedimentos metodológicos que nortearam a pesquisa e que foram adotados para a análise multitemporal da expansão urbana e evolução da população, durante o período de 1947 a 2014.

Para a análise multitemporal foram analisadas fotografias aéreas do ano de 1970, 1989, 1995 e imagens de satélite QuickBird do ano de 2005 e World View 2 de 2010 adquiridas junto a Prefeitura Municipal de Maringá (PMM).

Para a análise da evolução da população, foram utilizados dados dos censos promovidos pelo IBGE, detalhando a passagem em poucos anos, de uma população rural nos anos inicias pósfundação do município, para uma população predominantemente urbana nos dias atuais, a transformação referente ao panorama populacional também foi perceptível através do método de intervalos temporais, representados por décadas, sendo realizada a análise da evolução da população urbana em cada final do período delimitado.

A análise da evolução da malha urbana foi realizada com base nos dados coletados referente à colonização, urbanização e ao aumento populacional, adquiridos junto a PMM e IBGE, como também nos referenciais teóricos metodológicos obtidos junto às pesquisas já desenvolvidas por estudiosos em questão como Mendes (1992), Vercezi (2001) e Uehara (2012).

A análise da evolução da malha urbana seguiu o mesmo procedimento da análise da população, também foi elaborada por meio do método de intervalos temporais representados por décadas, para facilitar a compreensão e análise da evolução.

Com base nos dados fornecidos pela Prefeitura Municipal de Maringá e do estudo de Mendes (1992), Uehara (2012) e Vercezi (2001), foram elaborados de acordo com o objetivo da pesquisa, em destacar os parques, os mapas da evolução da urbanização de todas as décadas trabalhadas.

Observa-se aqui para que não se crie confusões, para melhor compreensão, que os mapas foram inseridos no fim de cada década, para saber o valor real da expansão urbana ao final de cada período, portanto, por exemplo, o mapa da expansão urbana relativo até o ano de 1960 foi inserido no subcapítulo da década de 1950, desta maneira, representando a totalidade da expansão durante toda a década. Os mapas da evolução urbana foram editados no software CorelDRAW X5 e as escalas foram geradas através do software ArcGIS 9.3. 
A análise do crescimento da população e da malha urbana foi realizada conjuntamente, pois, são inseparáveis, e a mudança de um processo afeta diretamente o outro, mas que de forma alguma apresenta-se como coincidência.

Portanto, foram caracterizados os processos mais significativos que afetaram a evolução e mobilização da população nas décadas de maior crescimento populacional de Maringá.

Antes da existência das imagens de satélite, existiam as fotografias aéreas obtidas por câmeras introduzidas em aviões, que na época correspondiam a melhor técnica de análise, esta técnica de fotointerpretação, com o auxílio do estereoscópio, era responsável por grandes mapeamentos, podendo ser utilizada também como instrumento para a análise multitemporal, como foi o caso da pesquisa.

Portanto, também se torna possível um estudo com essas fotografias aéreas, substituindo as imagens de satélites em períodos onde ainda não eram existentes ou acessíveis para a maioria dos pesquisadores.

Torres (2011, p. 30) sucintamente classifica análise multitemporal como sendo "o estudo de cenas de imagens de satélite, de mesmos locais, em diferentes períodos, visando avaliar as mudanças da paisagem apresentadas durante o tempo do estudo".

Dentro dessa nova realidade, Júnior e Almeida (2010), citam a importância destes trabalhos para os órgãos governamentais, que podem, por meio deles, realizar um planejamento mais adequado com informações precisas sobre o monitoramento das áreas verdes.

Soares e Alves (2004) frisam a importância desta técnica para medir a velocidade e a expansão da evolução da malha urbana, a qual permite a observação da mesma área em diferentes períodos, sendo imprescindível para o entendimento da forma e da intensidade da expansão urbana.

Ultimamente, muitas obras relacionadas à técnica de análise multitemporal vem surgindo, que se configura como um ótimo método de análise das transformações contidas na paisagem.

\section{RESULTADOS E DISCUSSÕES}

\subsection{Primeiro plano urbanístico e preocupação com as áreas verdes}

A primeira planta urbana da cidade, o projeto inicial, foi elaborada pelo urbanista engenheiro Jorge de Macedo Vieira em 1945. Para Remolli (2010), o plano inicial apresentou-se como bastante moderno para a época, de acordo com o autor, desde o plano inicial foi introduzido um espaço reservado para as áreas verdes, ou seja, praças e áreas com reservas florestais, como o Parque do Ingá e o Bosque II, que posteriormente, com o desenvolvimento da cidade, tornaram-se unidades de conservação do município. Essas reservas florestais são essenciais para a qualidade de vida da população até os dias atuais. 
$\mathrm{Na}$ época da implementação do plano piloto da cidade essas duas reservas projetadas por Jorge Macedo apresentavam-se como suficientes, isto, devido ao baixo número de população e de extensão territorial urbana até então. Portanto, nesta época, essas reservas ambientais juntamente com as praças e a arborização viária podiam ser consideradas ideais para a população.

O real problema é que com o crescimento intenso que a cidade sofreu apenas mais algumas reservas de tamanhos menores, com exceção do Horto Florestal foram criadas e o que antes era suficiente e ideal, atualmente é insuficiente e requerem mais espaços como esses inseridos na malha urbana da cidade, que atualmente encontra-se mais extensa. O município foi fundado em 10 de maio de 1947 ainda sem a nominação de município, tornando-se distrito de Mandaguari, e em 1948 elevou-se à categoria de Vila.

Segundo a Prefeitura Municipal de Maringá (2010) em 14 de fevereiro de 1951 Maringá foi elevada a município pela lei $\mathrm{n}^{\circ} 790$, possuindo na época três distritos, Iguatemi, Floriano e Ivatuba e apenas em 14 de novembro de 1951 conquistou sua autonomia política, elegendo seu primeiro prefeito.

O início da cidade pode ser descrito, de acordo com Remolli (2010), como a passagem rápida da etapa de mata virgem para um traçado urbanístico que obedecia a um plano previamente elaborado, por meio das características planialtimétricas, do relevo da região.

Luz (1997, p. 6/7) ressalta que "Muitos dos benefícios que as cidades mais antigas demoraram muito tempo para usufruir, em Maringá foram instalados em poucos anos".

A partir desta reflexão pode-se dizer que ficou evidente o tratamento especial que Maringá desfrutou no começo de sua existência, portanto, trata-se de um processo singular de colonização e expansão do espaço urbano, que revolucionou em certos aspectos o urbanismo brasileiro.

Os institutos IPEA/IBGE/UNICAMP/IPARDES (2000, p. 70) classificam Maringá como “aglomeração urbana de maior porte”. Maringá é definida como cidade de porte médio, esta classificação é descrita pelo site oficial da Prefeitura Municipal de Maringá.

A Prefeitura Municipal de Maringá (2010), estabelece que o começo do povoamento em Maringá teve início por volta de 1938, sendo que as primeiras edificações foram surgindo nos primeiros anos da década de 1940, na localidade conhecida até hoje por Maringá Velho.

Mendes (2013) determina que os principais motivos para a explosão da urbanização no município foram a posição geográfica estratégica, o crescimento demográfico, solos propícios a diferentes culturas e diversificação das atividades produtivas.

Deste modo, Maringá consolidou-se como centro urbano de relevância regional, já que estes fatores funcionavam como incentivo para investimentos na área, consequentemente, aumentando e expandindo a área urbana da cidade. 
Quanto à sua população, Maringá continua em pleno crescimento populacional, que por consequência promove a propulsão da demanda de construções na cidade.

Houve na cidade, décadas de maior destaque em relação ao crescimento populacional, assim como, a expansão da malha urbana, momentos de ápice desses processos, que aumentaram de forma significativa a população.

A análise dos crescimentos da população e da malha urbana foram realizados conjuntamente, pois são inseparáveis, e a mudança de um processo afeta diretamente o outro, mas que de forma alguma se apresenta como coincidência.

Portanto, foram caracterizados os processos mais significativos que afetaram a evolução e mobilização da população na área das décadas de maior crescimento populacional de Maringá.

\subsection{Análise Multitemporal da Expansão Urbana de Maringá aliada ao aumento populacional}

Nesta parte da pesquisa buscou-se levantar os estudos acerca da evolução urbana da cidade, a apropriação do espaço pela população, para desta maneira, conseguir analisar de uma forma conjunta, do porquê as matas nativas se encontrarem nessa situação nos dias atuais no território urbano do município.

\subsubsection{Décadas de 1940 e 1950}

Nas revisões de literatura sobre o assunto, Rodrigues (2004), com base nos relatos de Luz (1997), estabelece que a venda dos lotes urbanos começaram a ser efetuadas no ano de 1946, quando a Companhia Norte de Melhoramentos do Paraná - CNMP formalizou oficialmente 62 transações de venda dos lotes para os habitantes de Maringá, originando o que hoje é conhecido por Maringá velho (Figura 1).

Kerkhoff (2012) relata que três anos após sua fundação, em 1950, Maringá já apresentava: 1.200 casas, 6.000 propriedades rurais em todo o distrito, 4 associações esportivas e recreativas, 2 grupos escolares com 1.200 alunos, 16 escolas municipais e 5 escolas particulares, 3 hospitais, uma igreja matriz em construção além de 7 igrejas diversas, 4 bancos e em seu campo de aviação pousavam os aviões da VASP.

Deste modo, comprova-se o vertiginoso e acelerado desenvolvimento urbano do município, que com apenas três anos desde sua fundação já apresentava uma malha urbana considerável, como exposto na figura 1 , juntamente com potencial econômico necessário para que se acentuasse e crescesse ainda mais a urbanização. 


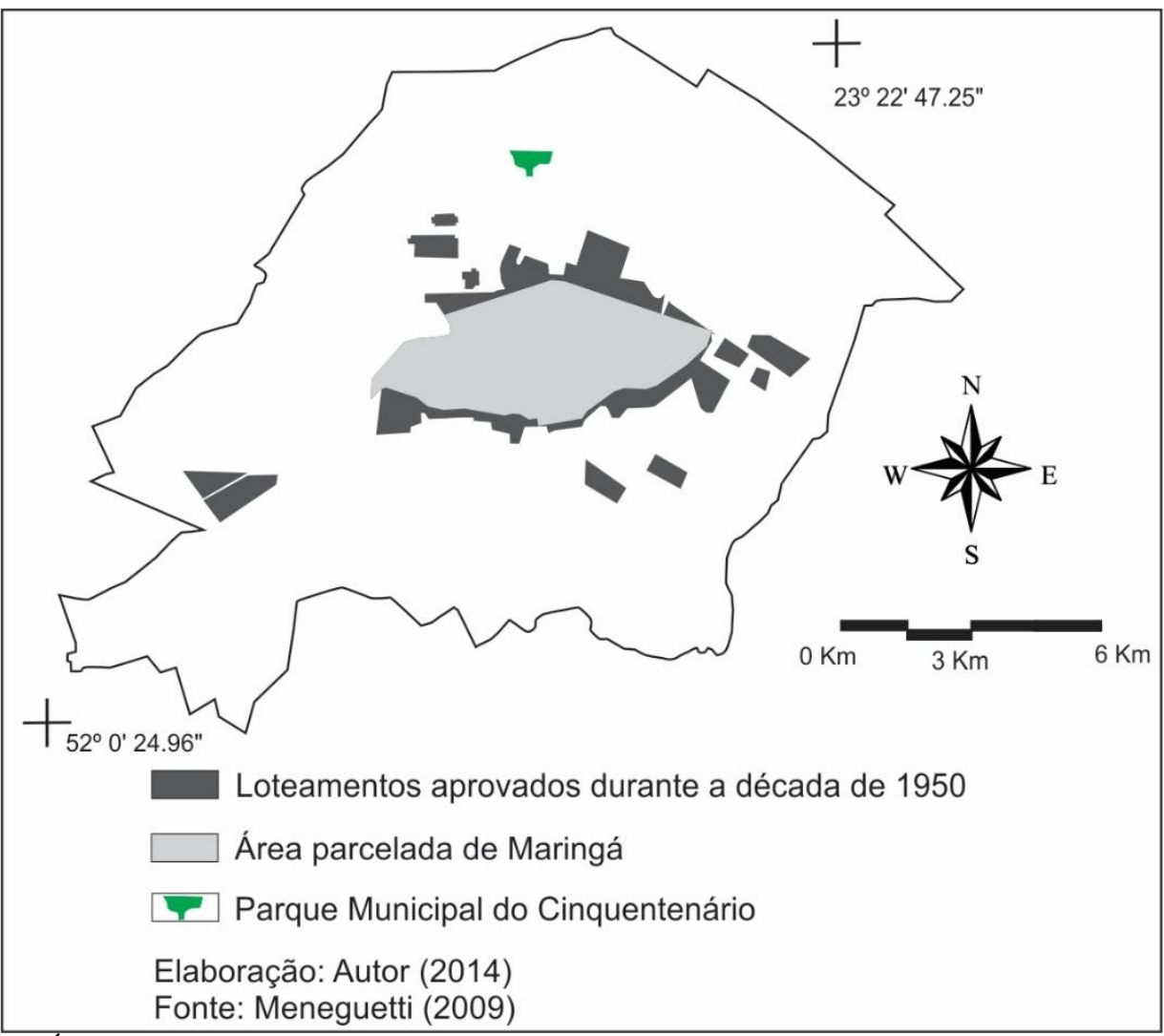

Figura 1: Área parcelada de Maringá (Década de 1950) e os 69 loteamentos aprovados nesse período.

Fonte: Adaptado de Meneguetti (2009)

A década de 1940, assim como a de 1950, são as únicas que apresentam uma população rural superior que a urbana na história do município e compõem uma época de intensos fluxos migratórios para a região (Tabela 1).

Segundo dados e registros do Instituto Brasileiro de Geografia e Estatística - IBGE (2010), até o ano de 1950 foram totalizados 38.588 habitantes no município.

Desta totalidade, 31.318 habitantes (Tabela 1), se situavam na área rural da cidade (população rural) e apenas 7.270 pertenciam à área urbana (população urbana). Dessa forma, Maringá configura-se nesta época como uma população amplamente rural, isto devido ao sucesso da economia cafeeira aplicado na região.

Tabela 1: Caracterização da população de Maringá (1950 - 2010)

\begin{tabular}{ccccc}
\hline Ano & $\begin{array}{c}\text { População } \\
\text { Total }\end{array}$ & $\begin{array}{c}\text { População } \\
\text { Urbana }\end{array}$ & $\begin{array}{c}\text { População } \\
\text { Rural }\end{array}$ & $\begin{array}{c}\text { Taxa de Urbanização } \\
\text { \% (População } \\
\text { Urbana/População } \\
\text { Rural) }\end{array}$ \\
\hline $\mathbf{1 9 5 0}$ & 38.588 & 7.270 & 31.318 & 18,84 \\
$\mathbf{1 9 6 0}$ & 104.131 & 47.592 & 56.539 & 45,70 \\
$\mathbf{1 9 7 0}$ & 121.374 & 100.100 & 21.274 & 82,47 \\
$\mathbf{1 9 8 0}$ & 168.239 & 160.689 & 7.550 & 95,51 \\
$\mathbf{1 9 9 1}$ & 240.292 & 234.079 & 6.213 & 97,41 \\
$\mathbf{2 0 0 0}$ & 288.653 & 283.978 & 4.675 & 98,38 \\
$\mathbf{2 0 1 0}$ & 357.117 & 349.120 & 7997 & 98,4 \\
\hline
\end{tabular}


Na época era mais lucrativa e visada a compra dos lotes rurais, já que a cultura do café se apresentava como uma atividade de alto lucro, mais do que a instalação no espaço urbano que ainda não contava com um núcleo comercial forte e atrativo, deste modo, explicando o porquê da concentração da população na área rural.

Segundo relatos de Teodoro e Amorim (2009), para que o núcleo urbano se expandisse, para que conseguisse atrair um bom número de pessoas, a companhia passou a doar um lote urbano ao comprador de um lote rural, uma forma que a empresa encontrou para apressar o desenvolvimento da cidade.

Kerkhoff (2012) fornece alguns dados essenciais responsáveis por dimensionar o processo de expansão urbana da época, segundo a autora, entre os anos de 1946 e 1952, foram vendidos 4.222 lotes na área urbana da cidade.

Dentro dessa nova realidade, Teodoro e Amorim (2008) relatam que durante a década de 1950 foram aprovados seis loteamentos não pertencentes ao projeto inicial. Verifica-se então que a partir deste momento, a cidade, o governo e a própria companhia responsável pelas vendas dos lotes já perdia o controle no sentido do planejamento que havia realizado até então.

Dentro desta ótica, Luz (1997) destaca o rápido crescimento urbano, num ritmo acelerado o que resultou até o final de 1952 mais de 2000 construções erguidas entre residências, casas comerciais e armazéns.

Em um estudo sobre a expansão urbana de Maringá, Mendes (1992) aponta que de 1947 a 1963 a área de ocupação horizontal sofreu um crescimento $6,48 \mathrm{~km}^{2}$ atingindo desta maneira a extensão de $10,72 \mathrm{~km}^{2}$, crescimento este, que segundo o autor direcionou-se em todos os quadrantes do perímetro urbano. Tendo em mãos tais informações e dados estabelecidos, pode-se analisar a evolução da malha urbana do município até o ano de 1960 (Figura 2).

A população da década de 1950 também se caracterizava pela predominância da população rural no município, só que de forma menos discrepante se comparado com a urbana.

Segundo dados e registros do IBGE (2010), até o ano de 1960 foram totalizados 104.131 habitantes no município (Tabela 1). Desta totalidade, 56.539 habitantes situavam-se na área rural da cidade e 47.592 pertenciam à área urbana.

A população rural de 1950 até 1960 sofreu um acréscimo de 80,53\% (Tabela 2). O que também se percebe é um acréscimo da população urbana do município no período de 1950 até 1960, que contou com um acréscimo de 554, 63\% (Tabela 2). 


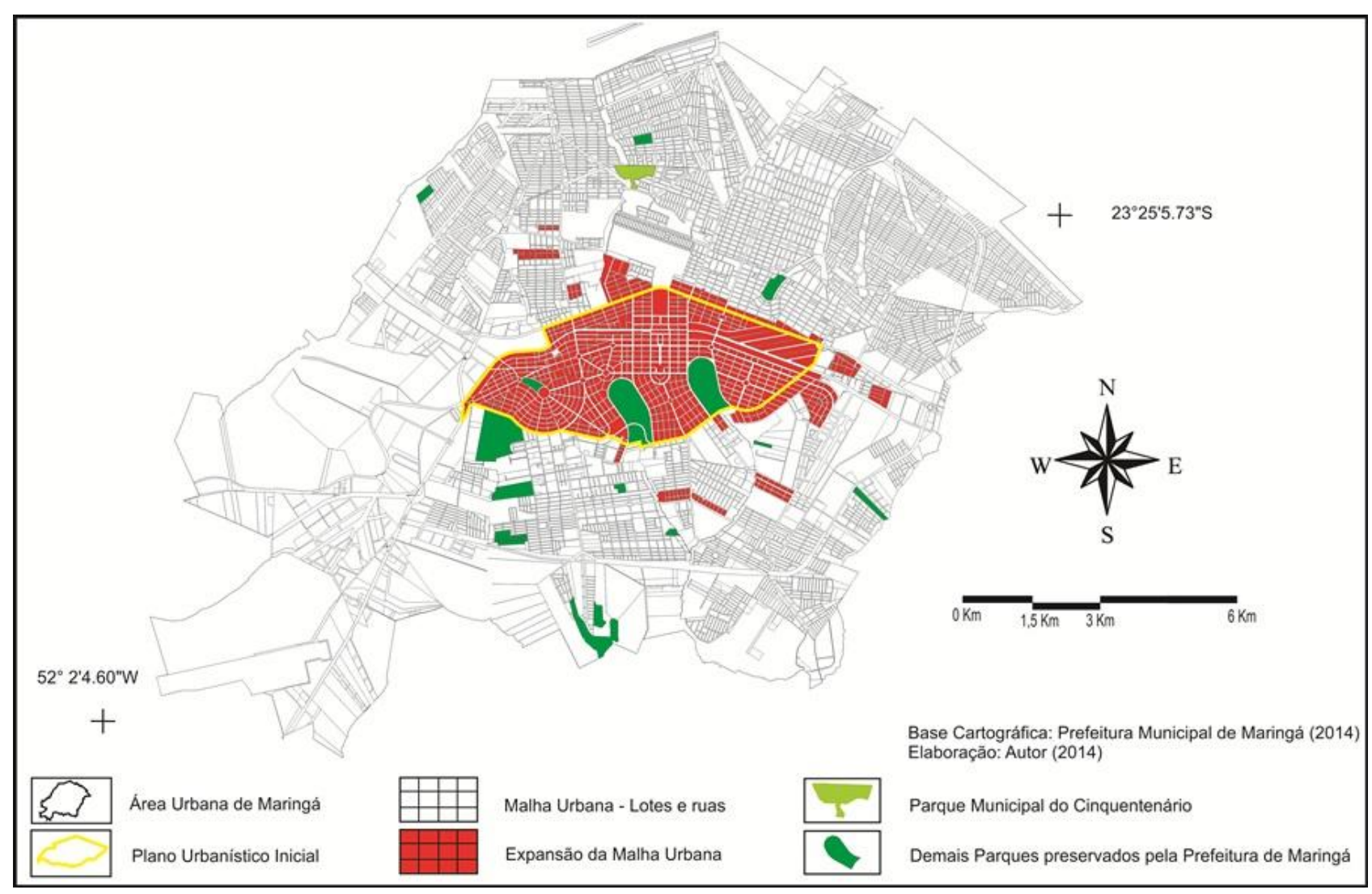

Figura 2: Evolução da malha urbana de Maringá (1947-1960)

Tabela 2: Taxa da evolução da população total, rural e urbana de Maringá de década para década

\begin{tabular}{cccc}
\hline Ano & População Total (\%) & População Urbana (\%) & População Rural (\%) \\
\hline $\mathbf{1 9 5 0 / 1 9 6 0}$ & 169,89 & 554,63 & 80,53 \\
$\mathbf{1 9 6 0 / 1 9 7 0}$ & 16,55 & 110,32 & $-62,37$ \\
$\mathbf{1 9 7 0 / 1 9 8 0}$ & 38,61 & 60,52 & $-64,51$ \\
$\mathbf{1 9 8 0 / 1 9 9 1}$ & 42,82 & 45,67 & $-17,70$ \\
$\mathbf{1 9 9 1 / 2 0 0 0}$ & 20,12 & 21,31 & $-24,75$ \\
$\mathbf{2 0 0 0 / 2 0 1 0}$ & 23,70 & 23,47 & 37,41 \\
\hline
\end{tabular}

Fonte: IBGE (2010); PMM (2010).

Isso se explica pelo fato do término da fase da implementação do plano inicial, com a materialização do projeto, criou-se um núcleo comercial organizado pela companhia, o que despertou a atenção de empreendedores comerciais para a região, que vieram para Maringá pela fácil comercialização e circulação dos produtos, devido à construção das ferrovias e rodovias, desta maneira começava a plena urbanização de Maringá sempre acompanhada de graves problemas ambientais.

Para Teodoro e Amorim (2009) a ascensão acentuada de evolução da população urbana do município na década de 1950 foi em função das oportunidades de estabelecimentos e empregos oferecidos em sua área urbana.

Endlich (1999), nos atenta para o fato de que em apenas 20 anos a população total multiplicou-se mais de dez vezes, caracterizando um crescimento acentuado. 


\subsubsection{Década de 1960}

A década de 1960 foi marcada pelo início do processo de verticalização da cidade, que na verdade, corresponde a uma alternativa para o aumento da densidade populacional sem expandir a malha urbana horizontal do município.

Mendes (2013) aponta que durante esta década houve o primeiro período de verticalização de Maringá, entre os anos de 1960 e 1969, no qual foram construídos 15 edifícios, produzindo uma área de $47.77 .66 \mathrm{~m}^{2}$.

Mendes (1992) alega que o principal fator responsável pela expansão vertical de Maringá foi consequência do excedente de capital oriundo de cultura cafeeira desenvolvida nas décadas de 1940 até a de 1970.

Neste sentido, Andrade e Cordovil (2008), exaltam que a verticalização efetuada nas zonas comerciais nesta década contribuiu imensamente para a densificação da área central e valorização das zonas comerciais, mas que gerou uma consequência, um processo de segregação social que envolveu o município, pois, a concentração destas construções comerciais nas principais vias da cidade fez com que o terreno se valorizasse, aumentando o valor do mesmo, segregando a população impossibilitada de adquirir um lote na região central, devido sua baixa renda.

Por meio destas afirmações pode-se verificar que a década de 1960 foi responsável pela expansão urbana no sentido norte da cidade (Figura 3), com a criação da Av. Morangueira e o Jardim Alvorada em que extrapolaram os limites urbanos traçados no plano inicial.

Em outro momento, Mendes (1992) descreveu o crescimento horizontal da expansão urbana no fim da década de 1950 e começo da década de 1960, mais especificamente o período de 1964 a 1973.

A área de ocupação horizontal sofreu um crescimento de $8,30 \mathrm{~km}^{2}$ em nove anos, que adicionado com os $10,72 \mathrm{~km}^{2}$ atingidos no ano de 1963 , totalizou $19,33 \mathrm{~km}^{2}$ de área horizontal, crescimento este que segundo o autor, direcionou-se fora da zona central da cidade, ficando na sua periferia.

Portanto, pode-se afirmar neste momento da pesquisa, que a expansão urbana de Maringá fora do traçado original, se concretizou efetivamente durante a década de 1960 com a expansão para o Norte, como exposto na figura 3.

Nota-se então que, desde a década de 1960, a expansão urbana se direciona em sentido ao Parque Municipal do Cinquentenário, já que o parque se localiza ao norte da planta inicial da cidade, ou seja, a expansão urbana nesta década já avançava rumo à unidade de conservação. 


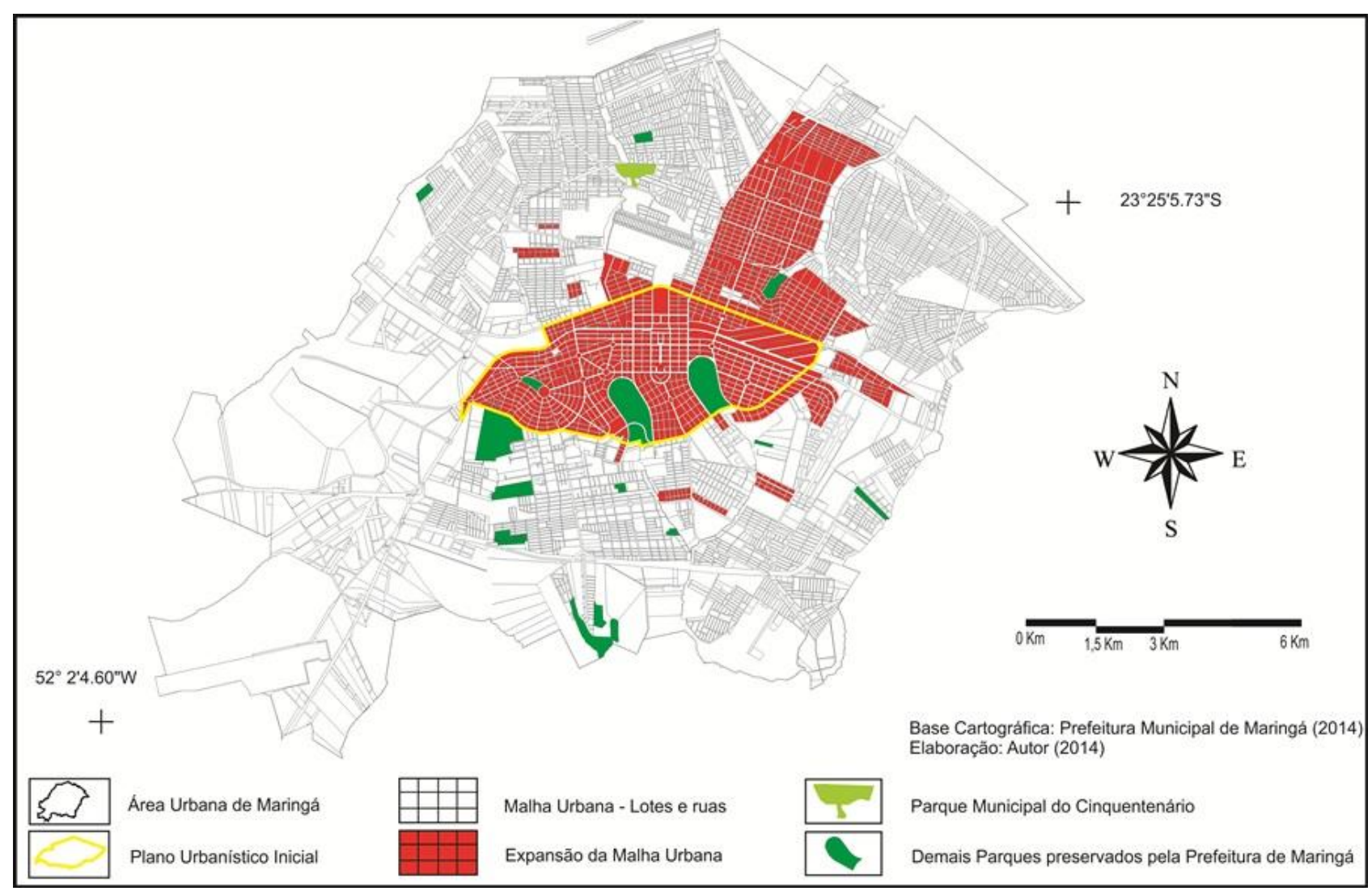

Figura 3: Evolução da malha urbana de Maringá (1960-1970)

Quanto à população, esta década caracterizou-se pela mudança em sua história, onde a população do município se tornou predominantemente urbana, com uma explosão demográfica urbana e uma contínua queda da população rural. O detalhe é que esta década caracterizou-se pelo menor crescimento populacional entre todas as décadas da cidade, o que aconteceu, principalmente, foi a troca da população da zona rural para a zona urbana sem um grande aumento da população devido ao êxodo rural.

Segundo dados e registros do IBGE (2010), até o ano de 1970, foram totalizados 121.374 habitantes no município. Desta totalidade apresentada na tabela 1, 21.274 habitantes situavam-se na área rural da cidade e 100.100 habitantes pertenciam à área urbana.

A população rural, de 1960 até 1970, sofreu um decréscimo de 62,37\%. Em contrapartida, a população urbana do município neste mesmo período obteve com um crescimento de 110, 32\%, como exposto na tabela 2, comprovando um êxodo rural de grande proporção que atingiu o município.

É claramente perceptível o aumento da população da zona urbana, que entre o período de 1960 a 1970 teve um aumento de 52.508 habitantes e a população da zona rural no mesmo período sofreu uma perda de 35.265 habitantes. 


\subsubsection{Década de 1970}

A década de 1970 ficou caracterizada pela intensificação do processo de periferização que o município já vinha sofrendo há alguns anos, assim como pelo significativo aumento populacional e o segundo processo de verticalização observado no município. A expansão urbana nesta década foi mais acentuada rumo à direção leste, sudeste e principalmente noroeste do município (Figura 4).

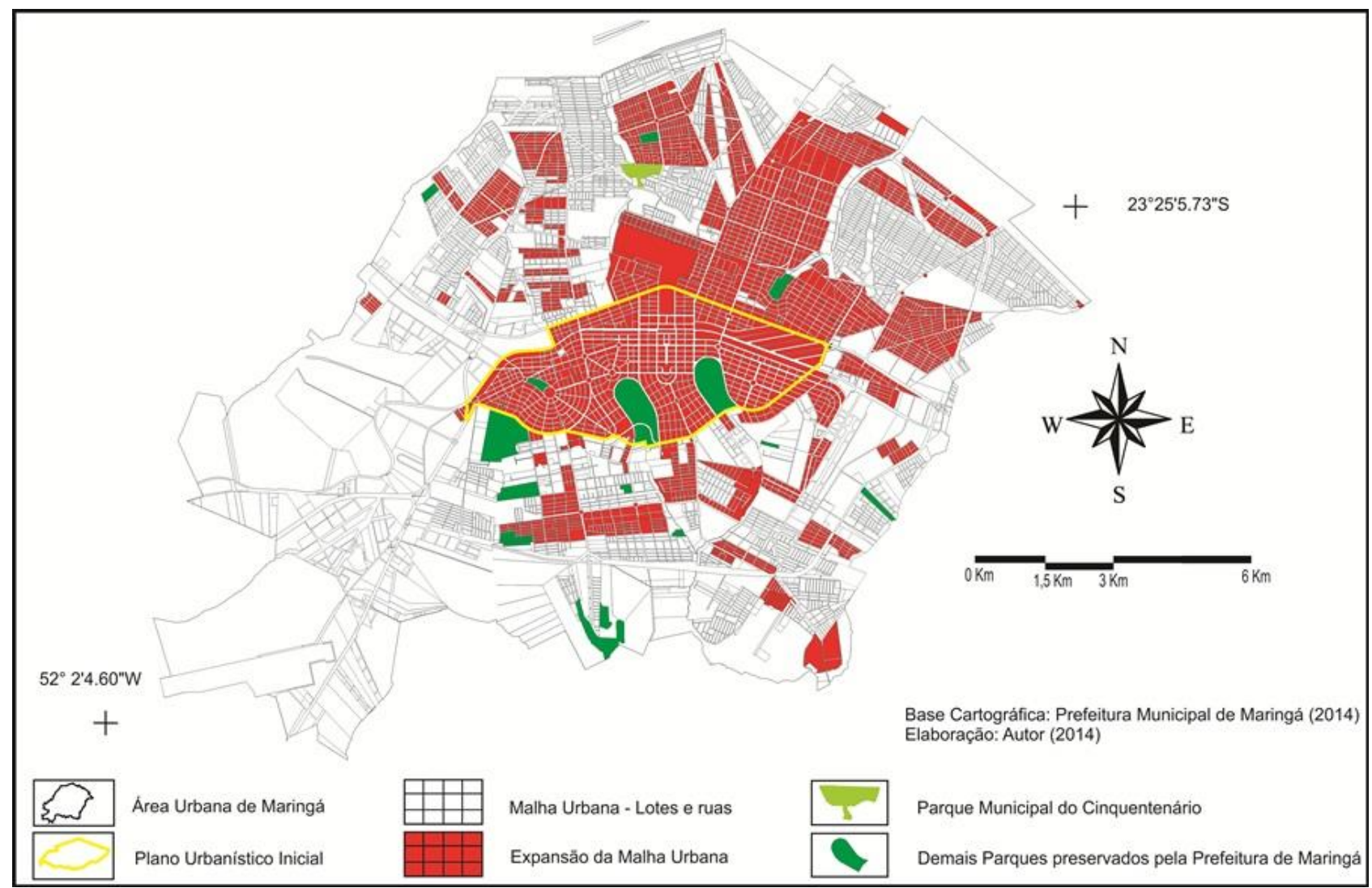

Figura 4: Evolução da malha urbana de Maringá (1970-1980)

Esta época é conceituada por diversos autores como um período de maior crescimento da cidade. Isto fica nítido quando comparamos os períodos de expansão da malha urbana expostos até aqui (Figuras 2, 3 e 4).

Nota-se que a urbanização no início da década de 1970 ainda não tinha atingindo as imediações norte do Parque Municipal do Cinquentenário (Figura 5), que contava ainda com uma boa preservação de seus recursos naturais. Mas, no final da década de 1970 a urbanização enfim se aproxima de suas áreas limítrofes, como se percebe analisando a figura 4, surgindo os primeiros processos de degradação nas reservas ambientais do município.

A expansão foi intensa, da mesma maneira, no município de Sarandi, a leste de Maringá, representando o início da conurbação entre as duas cidades. 


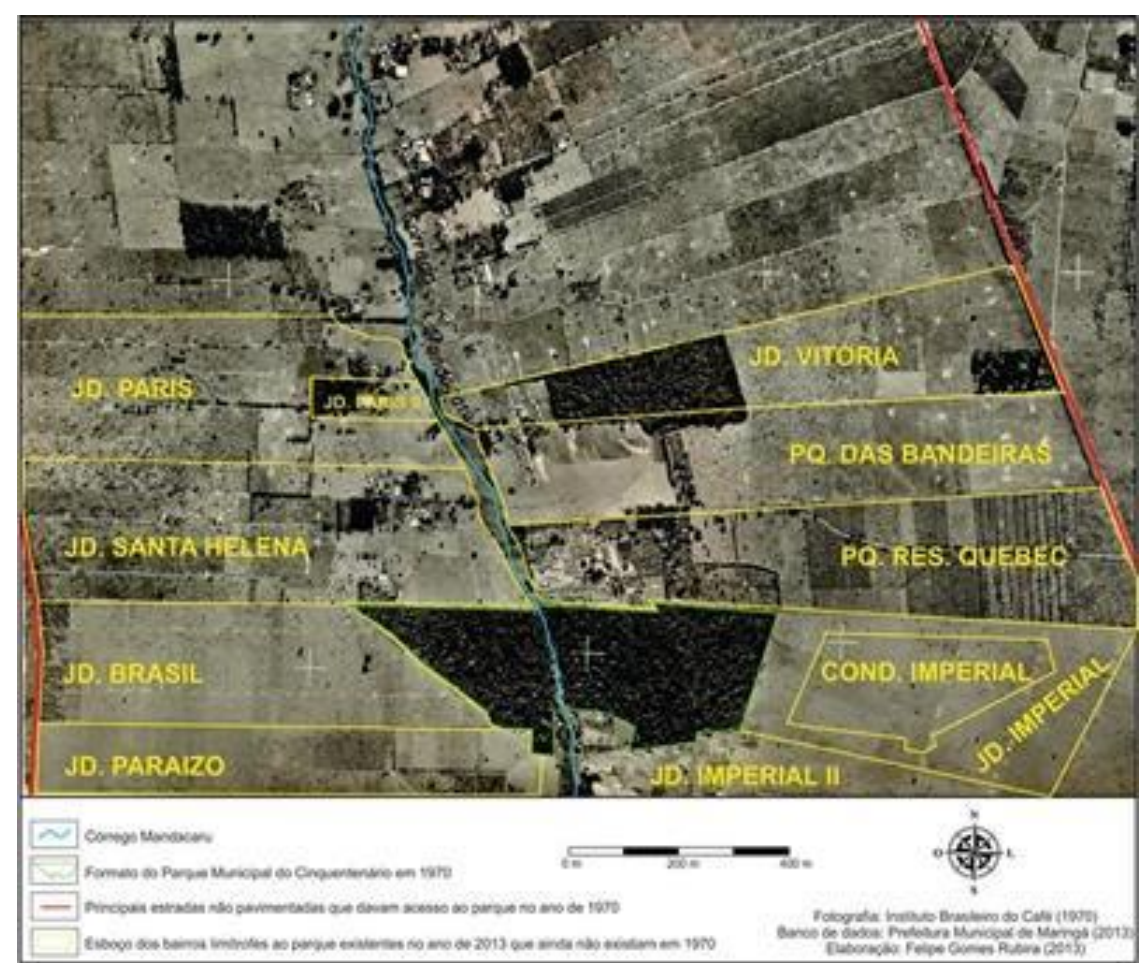

Figura 5: Fotografia aérea de 1970 da porção norte do município de Maringá-PR Fonte: Rubira (2014, p. 42).

Foram implementados 69 loteamentos nesta década (Figura 6), com destaque a porção norte limítrofe à área florestal que já começava a ser ocupada pela população, este processo causou vários impactos negativos, que originaram diversos processos de degradação ambiental no parque, constatados pelas imagens de fotografias aéreas.

Os loteamentos menos favorecidos de infraestrutura foram instalados em áreas mais longínquas do centro, já os dotados de infraestrutura foram crescendo nas imediações da área central, caracterizando deste modo uma periferização na cidade.

Mendes (1992) caracteriza que o crescimento ocorreu de forma praticamente uniforme nas áreas periféricas da cidade alcançando inclusive alguns pontos fora dos limites do perímetro urbano da época.

Nota-se um rápido crescimento ao analisar os dados fornecidos por Mendes (1992):

- no primeiro período, de 1947 a 1953, a área de crescimento inicial da cidade correspondeu a uma área de $4,24 \mathrm{~km}^{2}$;

- no segundo período, de 1954 a 1963, a área de crescimento da cidade correspondeu a $6,48 \mathrm{~km}^{2}$, somando-se com o crescimento de $4,24 \mathrm{~km}^{2}$ iniciais, atingiu uma área de expansão urbana até 1963 de $10,72 \mathrm{~km}^{2}$;

- no terceiro período, de 1964 a 1973, a área de crescimento da cidade correspondeu a $8,30 \mathrm{~km}^{2}$, somando-se com o crescimento de $10,72 \mathrm{~km}^{2}$ até o ano de 1963 , atingiu-se uma área de expansão urbana equivalente a 19,02km² até o ano de 1973. 
- no quarto período, de 1974 a 1983, caracterizado como o período de maior crescimento do município, a área de crescimento da cidade correspondeu a $28,60 \mathrm{~km}^{2}$, somando-se com o crescimento de $19,33 \mathrm{~km}^{2}$ até o ano de 1963, atingiu-se uma área de expansão urbana equivalente a $47,93 \mathrm{~km}^{2}$ até o ano de 1983.

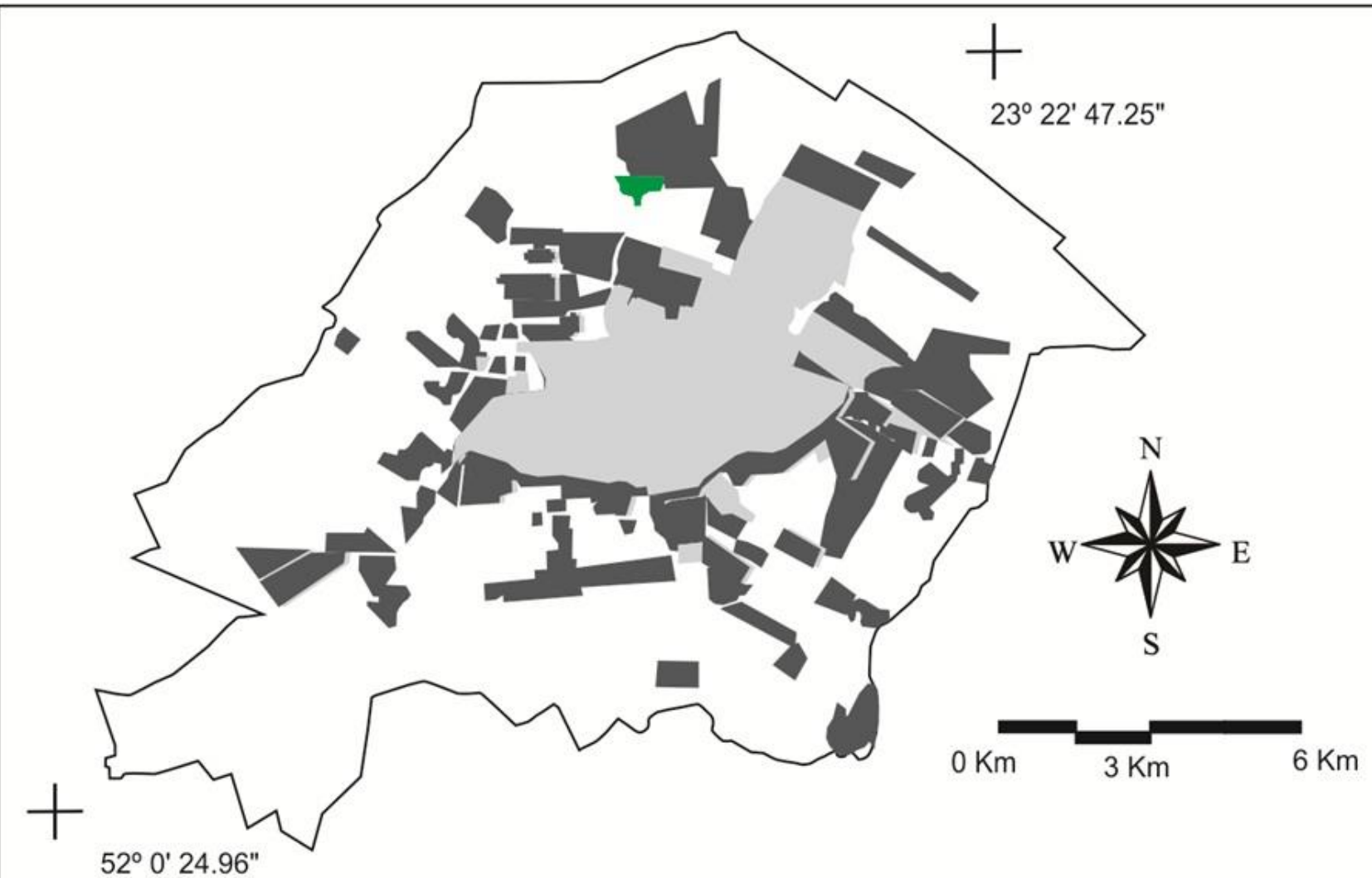

Loteamentos aprovados durante a década de 1970

$\square$ Área parcelada de Maringá

$\checkmark$ Parque Municipal do Cinquentenário

Elaboração: Autor (2014)

Fonte: Meneguetti (2009)

Figura 6: Área parcelada de Maringá (década de 1970) e os loteamentos aprovados nesse período

Fonte: Adaptado de Meneguetti (2009, p. 104)

Portanto, percebe-se o porquê da década de maior crescimento da malha urbana, pois, com a comparação acima, fica claro o aumento da área urbana do quarto período, se comparado com o crescimento dos outros três primeiros, saindo de $19,33 \mathrm{~km}^{2}$ de 1973 para $47,93 \mathrm{~km}^{2}$ em 1983 , mais que duplicando a malha urbana da cidade.

Outro aspecto, que caracterizou o crescimento urbano desta época, refere-se ao segundo processo de verticalização do município. De acordo com Mendes (2013), o segundo processo de verticalização constatado durante a década de 1970 produziu 39 edifícios, representando uma área de $135.73082 \mathrm{~m}^{2}$. 
Quanto à análise da população, esta década, também se caracterizou pela queda da população rural no município seguindo a tendência do último período analisado. Segundo dados e registros do IBGE (2010), até o ano de 1980, foram totalizados 168.239 habitantes no município.

Desta totalidade apresentada anteriormente na tabela 2, 7.550 habitantes se situavam na área rural da cidade e, 160.689 pertenciam à área urbana da cidade. Observa-se por meio destes dados a maior taxa de decréscimo em relação à população da zona rural de todas as décadas estudadas de 64,51\% (Tabela 2).

Pode-se observar também um acréscimo referente à taxa de urbanização de 95,51\% (Tabela 1), que na década anterior correspondia a $82,47 \%$. Um crescimento da taxa de urbanização equivalente a 13,04\%, tornando o município predominantemente urbano. Durante a década de 1970 houve um aumento de $38,61 \%$ (Tabela 2 ) na população total.

Teodoro e Amorim (2009) determinam que o crescimento da população urbana, claramente observado durante esta década, está relacionado com a concessão de incentivos fiscais, que tinham como objetivo a ampliação e melhora da infraestrutura urbana do município, desta maneira atraindo mais pessoas para o meio urbano, já que teriam consequentemente maior qualidade de vida.

A década de 1970 assim como a anterior, caracteriza-se ainda pelo processo de êxodo rural que envolveu a cidade.

Nesta década, houve uma modernização da agricultura em suas técnicas e equipamentos, substituindo muitos trabalhadores por processos mecânicos, pelas máquinas provenientes da modernização da agricultura, estes trabalhadores, sem escolha, foram se dirigindo a zona urbana da cidade em busca de trabalho e moradia, como consequência, foi ampliando-se o fluxo de pessoas em direção à zona urbana, fazendo a região perder, segundo Mendes (1992), 87.000 habitantes das zonas rurais para as zonas urbanas, em que o autor considera um dos maiores movimentos da história migratória brasileira.

Para o autor, o desenvolvimento observado no município de Maringá durante esta década, caracterizou-se como "rápido, dinâmico, com alta produtividade e em bases mais modernas, se comparada a outras regiões do Paraná e do país.” (Mendes, 1992, p. 52).

\subsubsection{Década de 1980}

A década de 1980 ficou caracterizada pelo terceiro processo de verticalização constatado no município, que se configurou segundo Mendes (1992), como o principal entre todos da cidade, em que finalmente houve a consolidação do processo.

Ao analisar a figura 3, comparando-a com a figura 4, percebe-se a nítida diferença do processo de urbanização entre a década de 1960 e a de 1970 . Na figura 4 referente à década de 
1970, nota-se facilmente que a expansão urbana caracterizou-se, principalmente, pela expansão horizontal da malha urbana.

Já na década de 1980, fica evidente que o processo de verticalização apresentou-se como predominante, fica nítido um processo de expansão da malha urbana horizontal muito menor (Figura 7) em comparação com a década anterior, em compensação, há no município um processo de verticalização acentuado.

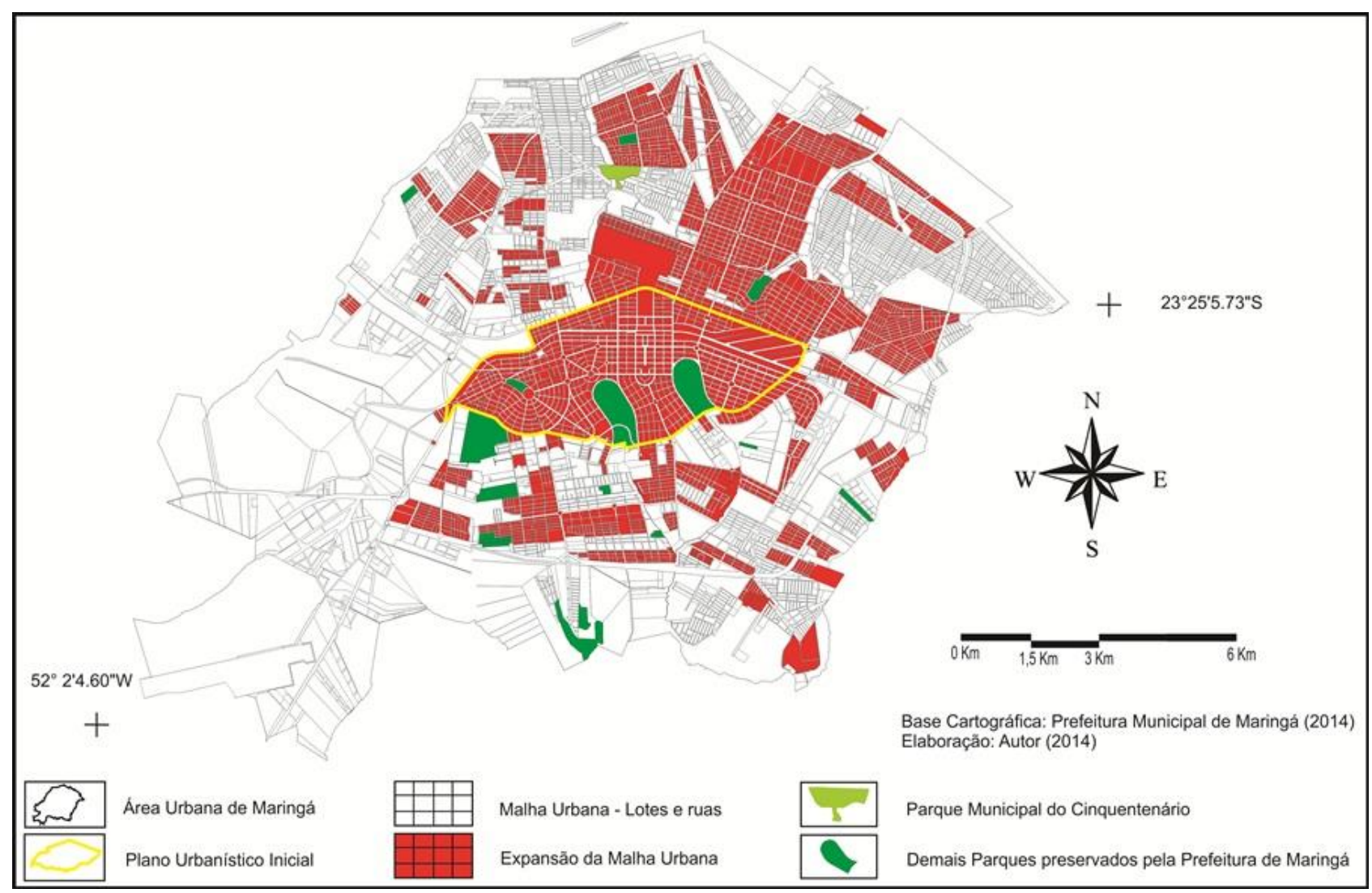

Figura 7: Evolução da malha urbana de Maringá (1980-1990)

Portanto, percebe-se que nesta década o processo de urbanização praticamente já envolveu o Parque Municipal do Cinquentenário em todas as direções (Figura 8), como já evidenciado na figura 7, surgindo na área os primeiros processos de degradação ambiental.

Por meio do estereoscópio verificou-se que a vegetação ciliar foi afetada, quase que totalmente desmatada diferentemente de 1970, quando ainda era preservada por espécies nativas.

O canal fluvial em 1989 também estava degradado, com diversas erosões marginais, com sérios problemas de assoreamento principalmente na parte que passa pelo parque, isso devido à retirada de vegetação de grande parte do córrego.

É perceptível também, que até o final desta década, poucos parques da cidade ainda não tinham contato com a expansão urbana do município. 
A década de 1980 também ficou marcada pela ocupação de muitos lotes vazios no centro, sendo a maioria para construção de prédios.

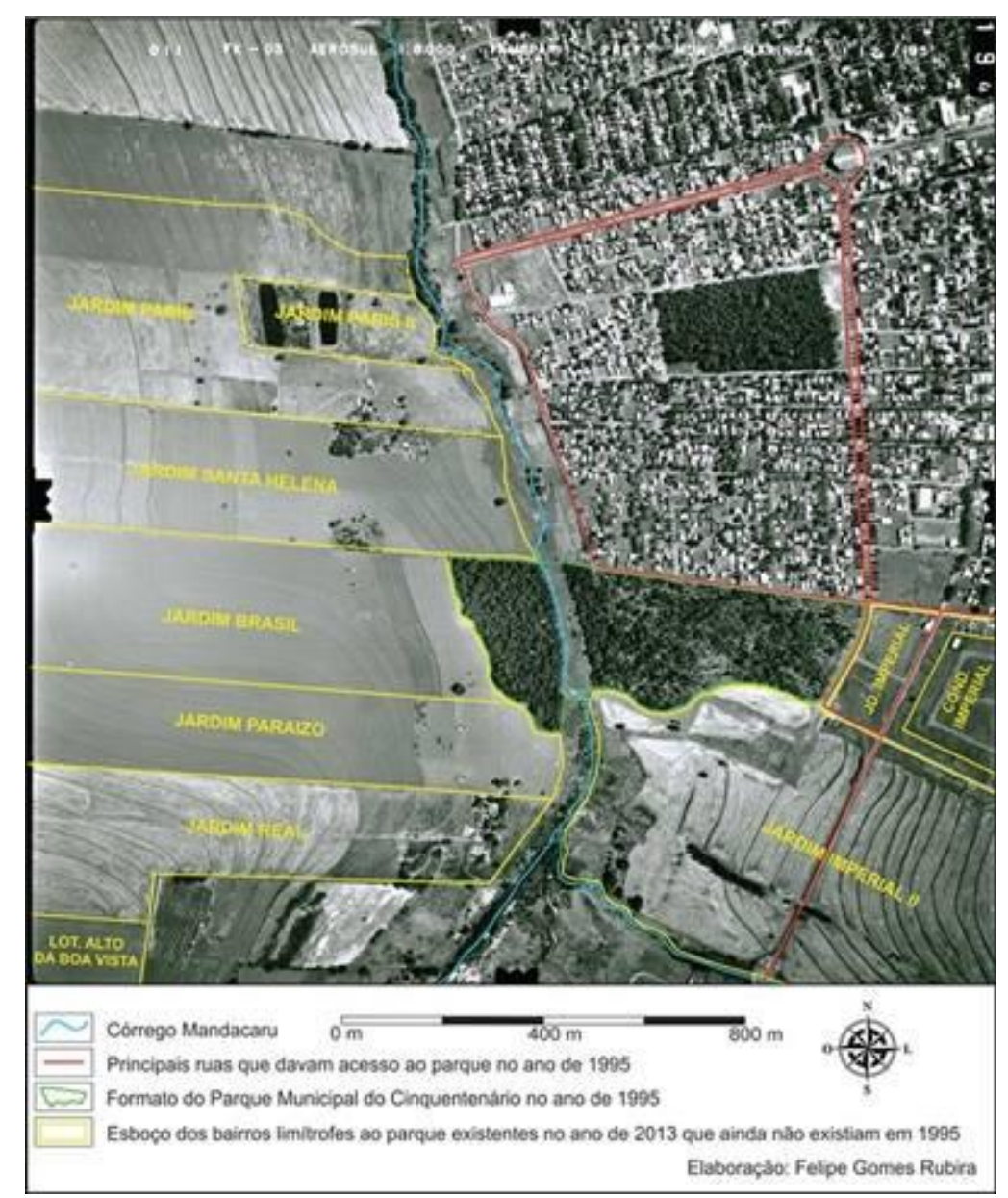

Figura 8: Fotografia aérea de 1989 da porção norte da área urbana do município de Maringá - PR (Rubira, 2014, p. 44).

Machado e Mendes (2013) destacam que esta década é representada pelo maior impulso já observado de verticalização da cidade, sendo construídos, ou estarem na época em processo de construção, 711 edifícios no período de 1980 a 1989, gerando uma área total de $2.455 .045 .59 \mathrm{~m}^{2}$.

Segundo Vercezi (2001), foram construídos edifícios de grande porte, sobretudo residenciais. Comportando mais pessoas em um mesmo espaço, houve um aumento da população em um espaço menor do que se abrigasse a mesma população em loteamentos horizontais, portanto, caracteriza-se um adensamento populacional.

Segundo a Prefeitura Municipal de Maringá (2010), entre 1984 e 1989 a expansão da malha urbana foi de $7,10 \mathrm{~km}^{2}$, representando um baixo índice de expansão urbana horizontal se comparado com o período anterior de 1974 a 1983 que obteve um crescimento de 28,60km². Deste modo, somando-se com os 7,10km² de expansão urbana entre período de 1984 a 1989, com os 47,93km² atingidos até o ano de 1983, observa-se um crescimento da expansão territorial horizontal de Maringá de 55,03km² até o ano de 1989. 
Quanto à análise da população, esta década, assim como as anteriores se caracteriza mais uma vez pela queda da população rural no município, configurando um pleno crescimento da população urbana.

Segundo dados e registros do IBGE (2010), até o ano de 1991, foram totalizados 240.292 habitantes no município. Desta totalidade já evidenciada na tabela 1, 6.213 habitantes situavam-se na área rural da cidade e 234.079 habitantes pertenciam à área urbana.

A taxa de urbanização do município mais uma vez se eleva, a população urbana aumenta com a adição de 73.390 habitantes, atingindo 97,41\% da população total do município. Já a população rural sofre um decréscimo de $-17,70 \%$, representando uma redução de 1.319 habitantes na zona rural.

O que se observa a partir desta década é uma desaceleração do crescimento demográfico, pois, as próximas duas décadas atingiram uma evolução da população total bem abaixo, se comparado com o crescimento da população total da década de 1980, intimamente ligada ao terceiro processo de verticalização.

\subsubsection{Década de 1990}

Na década de 1990 nota-se a aprovação de vários loteamentos na cidade, ocupando vazios demográficos principalmente a sudoeste.

Esta década não produziu uma expansão urbana significativa como nas décadas anteriores, seja por processos de verticalização ou implantação de loteamentos horizontais, consequentemente não houve um grande salto no número da população neste período, como ocorreu nas décadas anteriores. Esta década ficou marcada pelo início da conurbação com Paiçandu.

Percebe-se a evolução da expansão urbana maringaense caracterizada até o final da década de 1990 (Figura 9).

Nota-se cada vez mais a apropriação do espaço no entorno do Parque Municipal do Cinquentenário, que até o final da década de 1990 encontrava-se quase que totalmente envolvido pela intensa urbanização da bacia do córrego Mandacaru.

Quanto aos processos de degradação, por meio do estereoscópio verificou-se que a vegetação ciliar foi mais desmatada e a vegetação arbórea no interior do parque estava em um estado deplorável com inúmeras clareiras, devido à consolidação do bairro limítrofe ao parque (Figura 10). Verificou-se que os processos de degradação ambiental são os mesmos que em 1989, não houve a adição de novos processos, mas sim uma intensificação. 


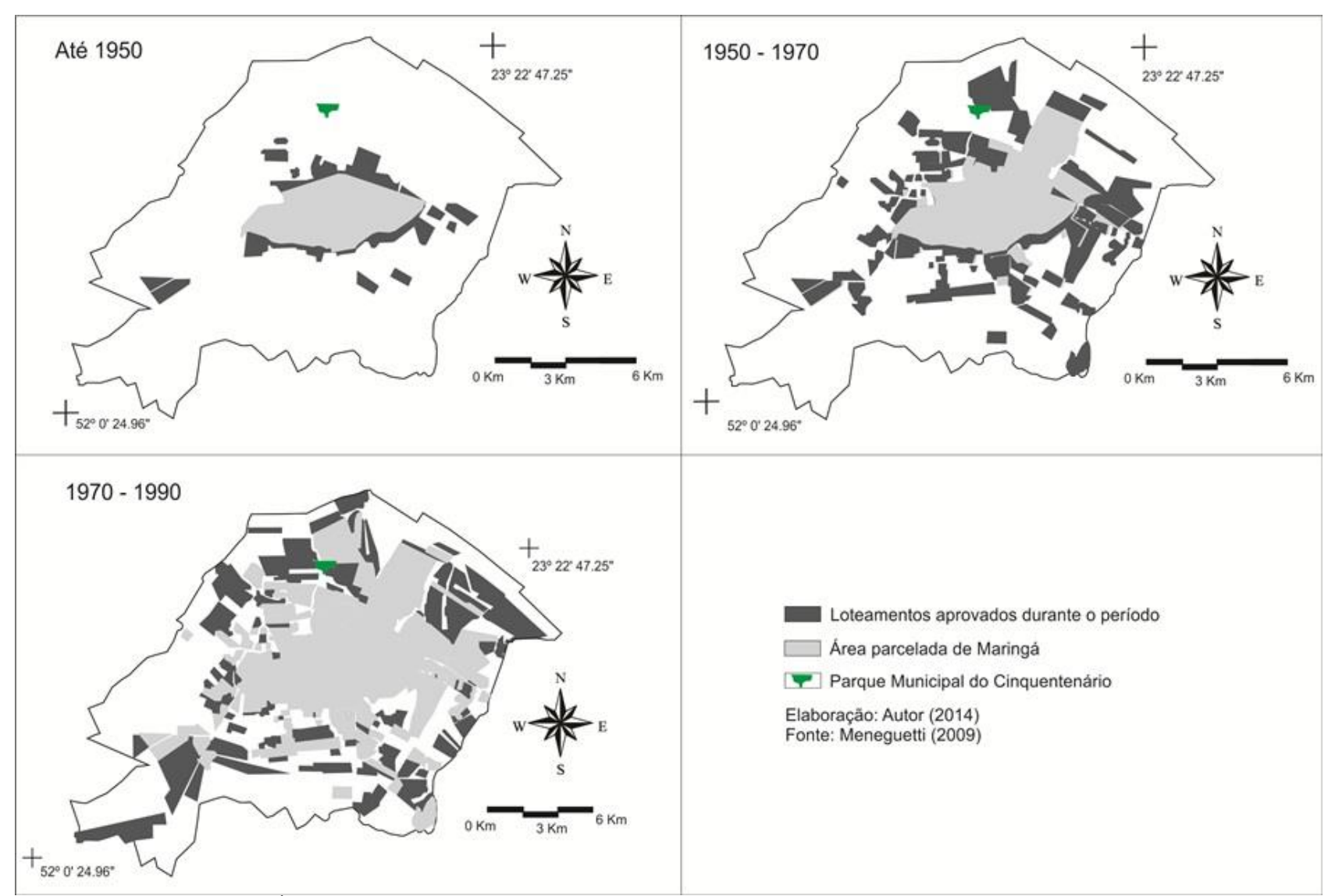

Figura 9: Área parcelada de Maringá (1950 a 1999) e os loteamentos aprovados nesse período Fonte: Adaptado de Meneguetti (2009, p. 104).

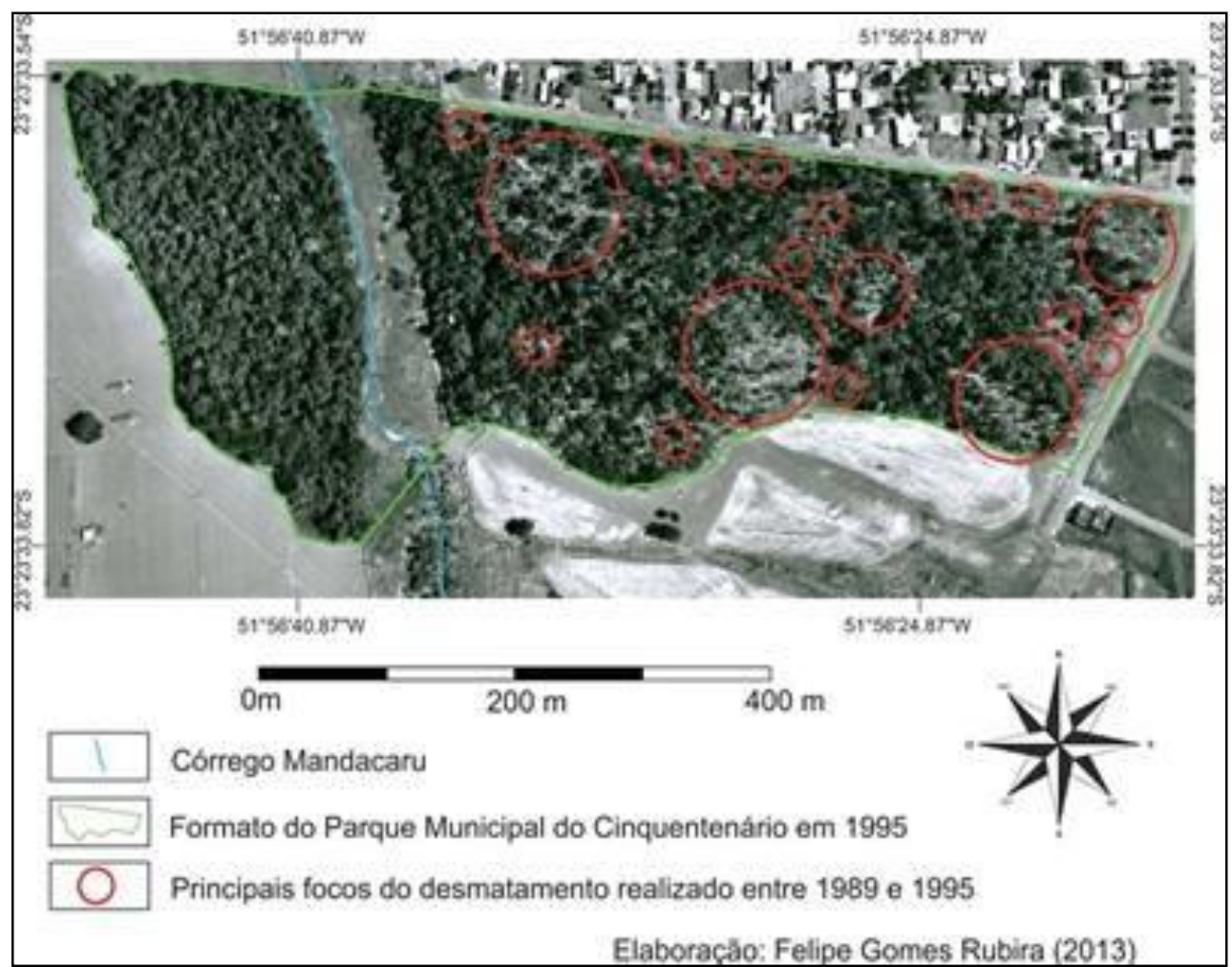

Figura 10: Principais focos de desmatamento até o ano de 1995 Fonte: Rubira (2014, p. 49). 
Quanto à análise da população, a década de 1990 assim como na década 2000, fica claro um desenvolvimento equilibrado dos setores populacionais, observa-se uma baixa taxa de crescimento populacional se comparada com as décadas anteriores.

Segundo dados e registros do IBGE (2010), até o ano 2000, foram totalizados 288.653 habitantes no município. Desta totalidade, já apresentada na tabela 2, 4.675 habitantes situavam-se na área rural da cidade e 283.978 habitantes pertenciam à área urbana.

A década de 1990 obteve uma evolução da população total de 20,12\% (Tabela 2) em comparação com o ano de 1980, o que representou um acréscimo de 48.361 habitantes em Maringá.

A zona urbana mais uma vez é a grande responsável pelo crescimento da população com um crescimento de 21,31\% (Tabela 2), representado pela adição de 49.899 habitantes. A zona rural sofreu um decréscimo de 1.538 pessoas, e em relação à década anterior de 1980 de -24,75\% (Tabela 2). Este processo de desaceleração, referente ao crescimento da população do município, a partir de 1991 também foi verificado por Reschilian e Uehara (2012), os autores apontam que este processo que se sucedeu neste período também foi verificado em outras cidades brasileiras, constituindo-se como um reflexo do modelo de urbanização brasileiro.

Reschilian e Uehara (2012) apontam que esta desaceleração ocorreu devido à expansão populacional dos municípios vizinhos, que absorveram grande parte da população que se dirigia para a região devido aos preços mais rentáveis dos terrenos se comparados aos de Maringá.

\subsubsection{Década de 2000}

A década de 2000 transparece uma urbanização já consolidada, ainda mais quando se compara o projeto inicial de Jorge Macedo Vieira com a malha urbana presenciada atualmente na cidade (Figura 11).

As décadas de 1990 e 2000 tiveram como principal característica, nesse período de expansão, o preenchimento dos espaços vazios localizados no perímetro urbano da cidade.

Como percebe-se, nessas décadas, as áreas limítrofes ao Parque Municipal do Cinquentenário foram amplamente ocupadas por loteamentos construídos nesse período, principalmente na década de 1990.

Nota-se (Figura 12), a densa malha urbana desenvolvida nas duas últimas décadas em relação ao Parque Municipal do Cinquentenário que, principalmente ao Norte da reserva já está intensamente ocupada, este processo gerou impactos diretos na reserva florestal. 


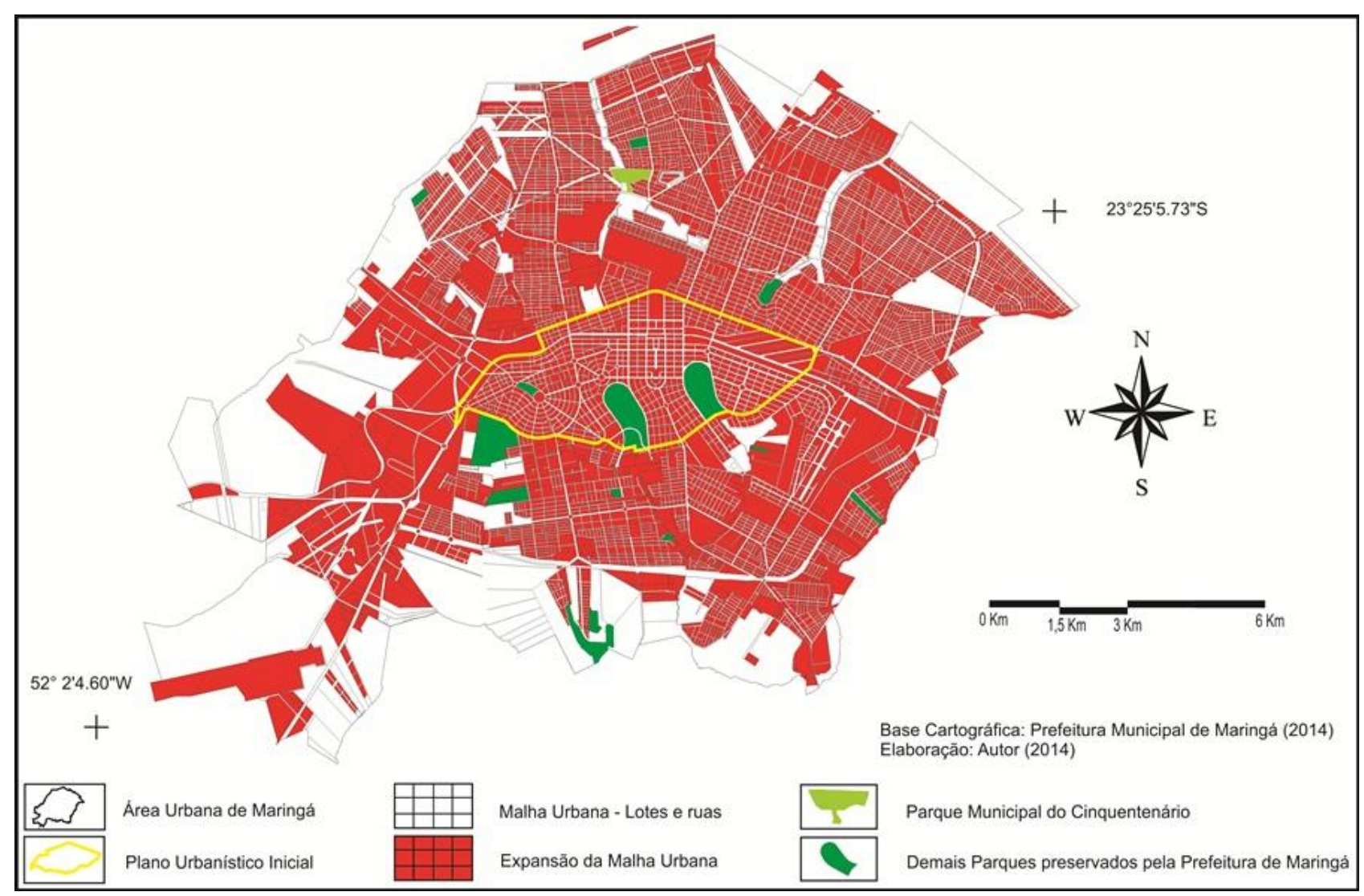

Figura 11: Evolução da malha urbana de Maringá (1990-2014)

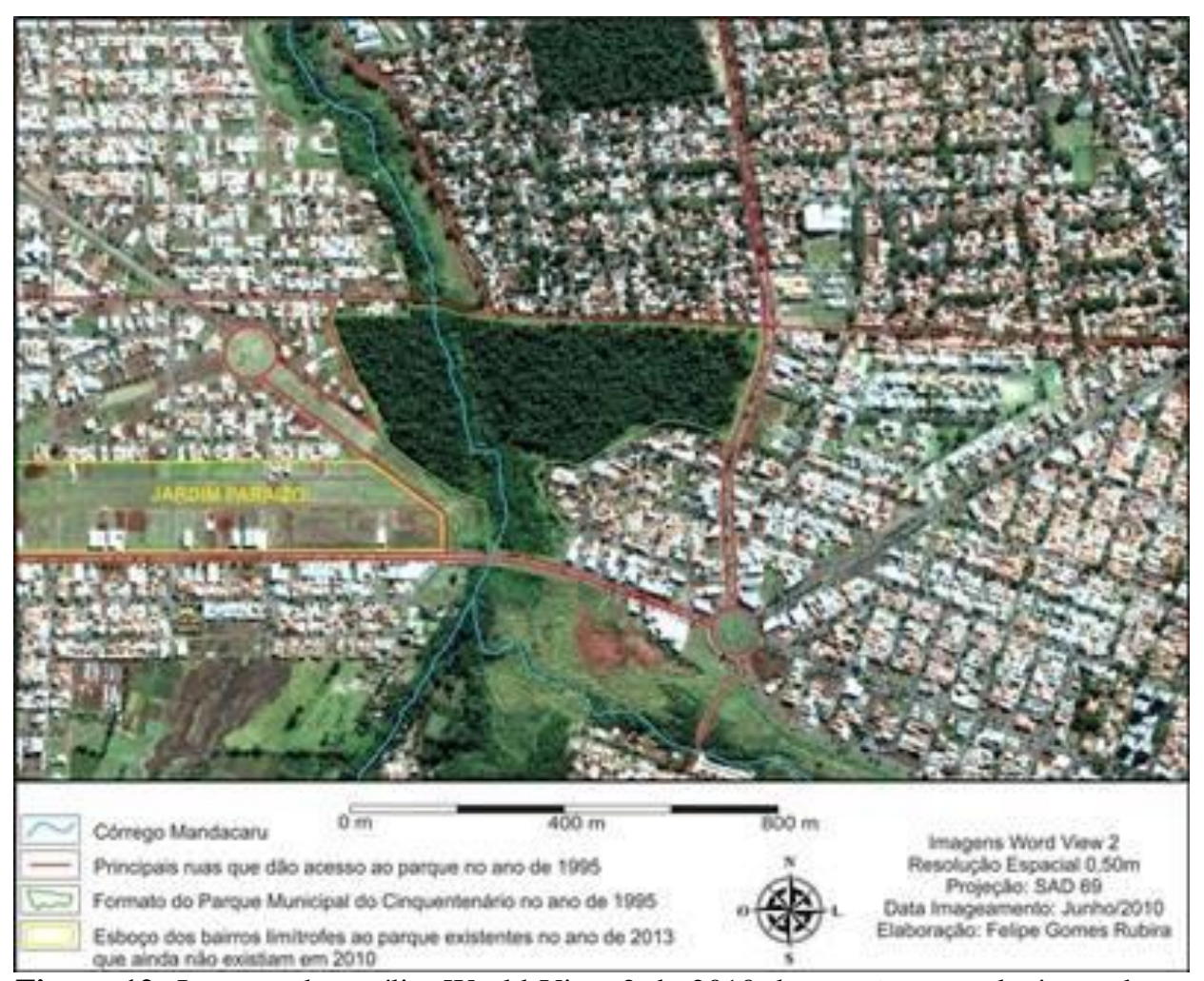

Figura 12: Imagem do satélite World View 2 de 2010 da porção norte da área urbana do município de Maringá (RUBIRA, 2014, p. 53). 
Em 2010, os processos de degradação do canal fluvial (erosão) e da vegetação (desmatamento) ainda estavam presentes no parque, mas, o que mais preocupava neste ano, era o estado do solo, pois, desde o ano de 2005 o parque já apresentava duas feições erosivas de maior porte, uma dentro de seus limites em sua área limítrofe. Houve uma regeneração da vegetação, mais repleta de espécies invasoras, principalmente a Leucena (Leucaena leucocephala).

Todas as outras áreas protegidas também foram atingidas pelo processo de urbanização, tendo seus limites agora envolvidos por lotes e construções.

Dessa forma, na década de 2000, esses loteamentos construídos começaram a ser ocupados por residências, portanto, sofreram um rápido adensamento populacional, que acabou afetando alguns recursos naturais das reservas florestais.

A tendência é de que a urbanização avance em direção das zonas rurais próximas ao perímetro urbano, exercendo novamente um processo de degradação ambiental, pois, muitas áreas que contam com vegetação serão desmatadas para construção das edificações.

Algumas áreas que ainda contam com o resquício de mata original serão preservadas, objetivando, mais uma futura especulação imobiliária, com a valorização do terreno por causa da área verde (assim como ocorre com o Bosque II, Parque do Ingá, Horto Florestal entre outros) e lucros com o ICMS ecológico, do que, para garantia a plena qualidade de vida da população local.

Verifica-se, que até o ano de 1970, o Parque Municipal do Cinquentenário se localizava fora do perímetro urbano da cidade (Figura 13), no ano 2000, percebe-se o avanço do perímetro urbano da cidade sobre o parque, assim como de sua malha urbana, comprovando que as primeiras modificações realizadas na reserva florestal surgiram na década de 1970, ou seja, os primeiros sinais de degradação presenciados na reserva, por meio de fotografias áreas, foram constatados após 1970, década em que o perímetro urbano atinge o parque.

Uehara (2012) caracteriza de forma sucinta o processo de urbanização maringaense relacionado com a preocupação ambiental:

Ao analisar os planos urbanos produzidos ao longo desse período [...] nota-se que o maior objetivo não foi atingido para seus habitantes: a conservação do meio ambiente, dentre outros aspectos, até o princípio de terra para todos. (UEHARA, 2012, p. 42; grifo meu).

Tal crescimento acentuado da urbanização em pouco tempo é evidenciado por Netto e Sant'Ana (2011), os autores discutem de forma comparativa a taxa de urbanização dos municípios da região metropolitana e das principais cidades do estado.

Até 2010, o estado do Paraná atingiu uma taxa de $85 \%$ de urbanização, o crescimento da urbanização de Maringá foi tão estrondoso que atingiu uma taxa de urbanização extrema, ficando somente abaixo de Londrina e Curitiba, sendo sua população em sua maioria esmagadora urbana. 
Por meio da junção de todos os mapas (Figura 14) apresentados até aqui, pode-se perceber como a urbanização foi se apropriando do vazio demográfico existente no primeiro mapa até 2014.

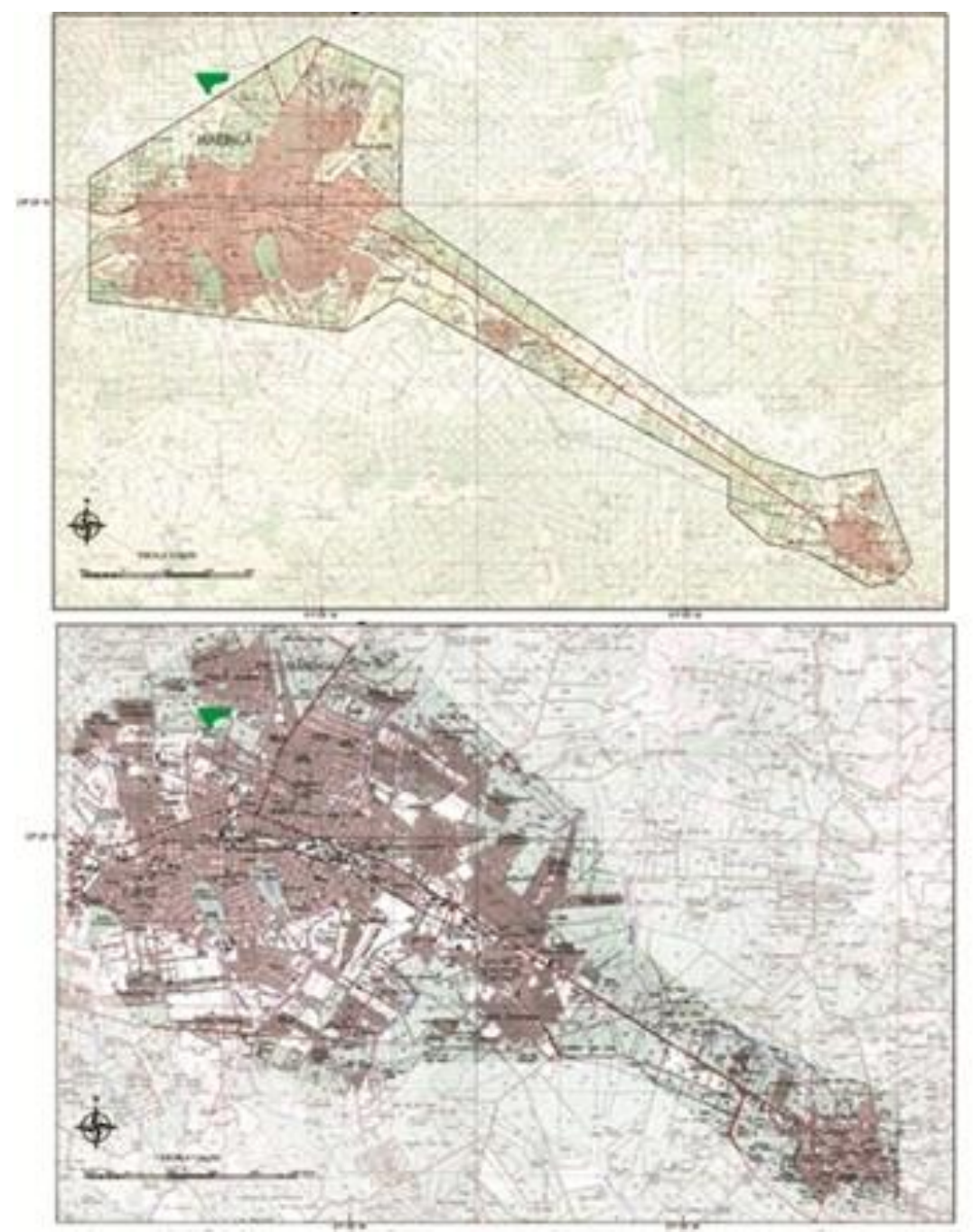

Figura 13: Malha Urbana de Maringá, Sarandi e Marialva no período de 1970 a 2000

Fonte: Ministério do exército - Departamento de Engenharia e Comunicações. Adaptado de Vercezi (2001, p.111)

Para Netto e Sant'Ana (2011), a explosão do crescimento do espaço urbano da cidade acompanhado da explosão demográfica em um curto período de tempo, se comparado com as demais cidades paranaenses, resultou em um valioso crescimento econômico para o município, mas que "muito se deixou a desejar no que se refere ao meio ambiente" (NETTO, SANT'ANA, 2011, p. $13)$.

Dentre esses e outros fatores, percebe-se realmente que a urbanização e a ocupação urbana, principalmente nas áreas de fundo de vale, acarretaram uma série de processos de degradação atuantes no meio físico do município, situação mantida até os dias atuais, uma herança pretérita, negativa, que vem se arrastando desde o processo de colonização do município, isso é perceptível por meio da análise da situação dos fundos de vale e córregos urbanos da cidade. 


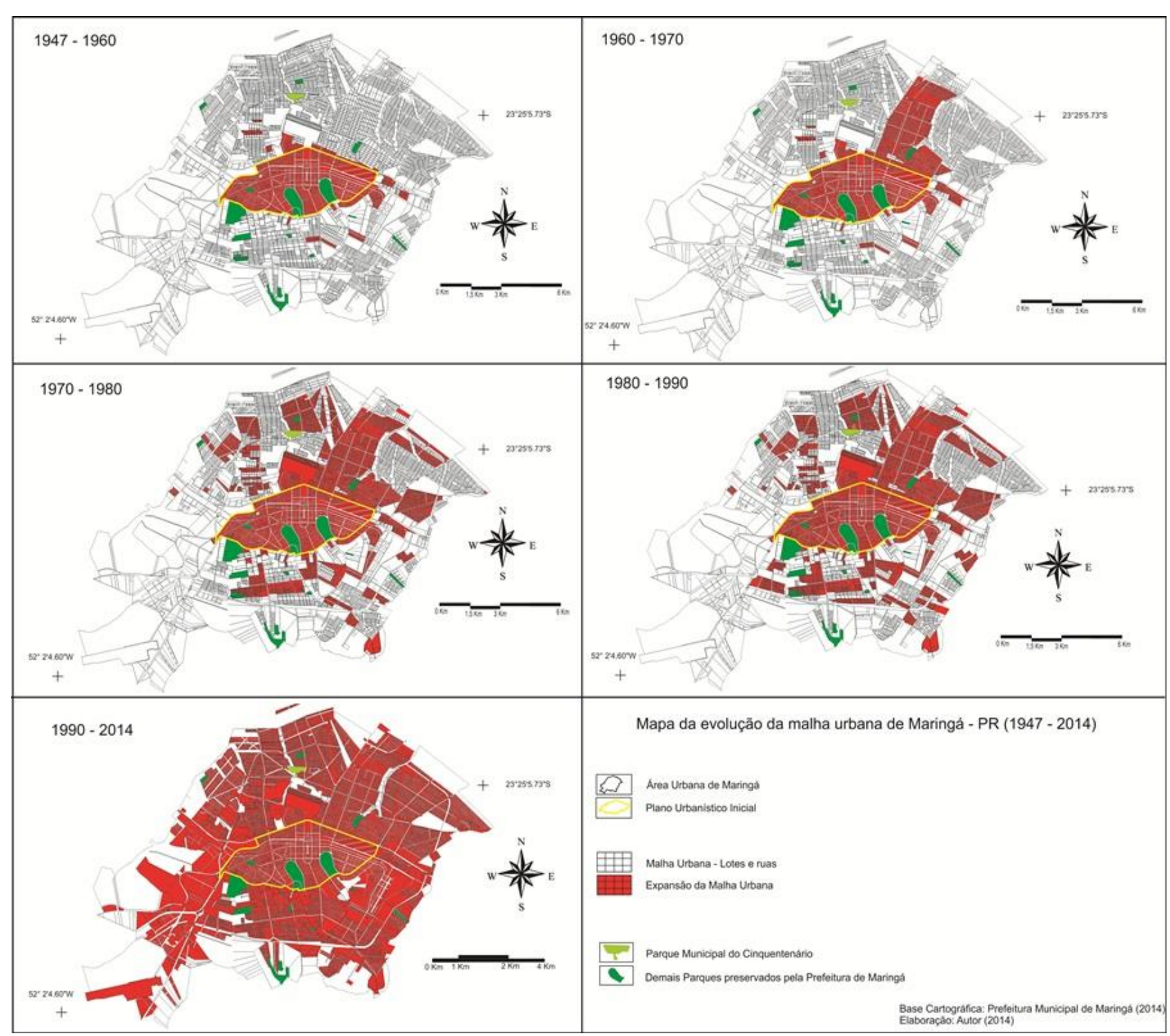

Figura 14: Mapa síntese da evolução da malha urbana (1947 - 2014)

Quanto à análise da população, esta década se diferencia das demais em um aspecto, a volta da evolução da população rural do município que vinha em queda desde a década de 1960, em que ano após ano via sua população rural se desvincular da zona rural e se direcionar para a zona urbana como mostrado na tabela 2.

Segundo dados e registros do IBGE (2010), até o ano de 2010, foram totalizados 357.117 habitantes no município. Desta totalidade, 7.997 habitantes se situavam na área rural da cidade e 349.120 habitantes pertenciam à área urbana da cidade.

Após cinco décadas, a população rural do município tem uma evolução de $37,41 \%$ em relação ao período de 1991 a 2000 (Tabela 2).

O crescimento verificado para a população urbana, no período de 2000 a 2010, foi de 23,47\%, com uma adição de 65.142 habitantes (Tabela 2).

A população rural sofreu um crescimento de 37,41\% (Tabela 2) neste período, comparado a com a década anterior, houve uma adição de 3.322 habitantes na zona rural, um número 
relativamente pequeno, mas se comparado quanto a proporção de evolução entre um período e outro se apresenta como a maior entre todas as décadas, exceto ao período analisado de 1950 a 1960 (Tabela 2). A população total do município obteve um crescimento de $23,70 \%$, representando uma adição de 68.464 habitantes (Tabela 2).

Do ponto de vista geral, de toda a análise multitemporal proferida até o momento, verificase um predomínio da população rural sobre a população urbana nas décadas iniciais da cidade representadas pelo período de 1947 a 1960.

Durante a década de 1970, é perceptível o início da ascensão da população urbana. Observase, que a maior expressão da população rural ocorreu no final da década de 1960, com 56.539 habitantes, ficando explicito o movimento de êxodo rural que a cidade sofreu ao longo das décadas, perdendo sua força e intensidade durante as décadas de 1980 e 1990, até a década de 2000, que conta com um incremento populacional rural novamente.

Verificou-se, que o crescimento da malha urbana associada com o aumento populacional da cidade de Maringá, foi evoluindo, para isso, era necessário espaço, para que todas as construções fossem realizadas para o desenvolvimento da cidade.

Desta maneira, foi caracterizando-se um processo marcante na história ambiental do município, em que na maioria dos casos e muito frequentemente, as áreas verdes da cidade, as matas que ali estavam, foram amplamente desmatadas, restando apenas pequenas manchas de mata nativa, pequenos fragmentos encontrados hoje na cidade, como o Parque Municipal do Cinquentenário.

Neste sentido, mostrou-se necessário explicar, como se desenvolveu todos esses fatores urbanos e populacionais que contribuíram para a análise da formação dos processos de degradação, que envolve o Parque Municipal do Cinquentenário e as demais áreas verdes protegidas do município, não basta apenas apontar a causa, mais sim entender todos os processos responsáveis pela origem destes processos de degradação ambiental.

\section{CONCLUSÕES}

Conclui-se, que a década de 1940, assim como a de 1950, são as únicas que apresentam uma população rural superior que a urbana na história do município e compõem uma época de intensos fluxos migratórios para a região, época marcada pelo início da urbanização em Maringá.

A década de 1960 foi marcada pelo início do processo de verticalização da cidade, que na verdade, corresponde a uma alternativa para o aumento da densidade populacional sem expandir a malha urbana da cidade horizontalmente. 
A década de 1970 ficou caracterizada pela intensificação do processo de periferização que o município já vinha sofrendo há alguns anos, assim como pelo significativo aumento populacional e o segundo processo de verticalização observado no município.

A década de 1980 ficou caracterizada pelo terceiro processo de verticalização constatado no município, que se configurou segundo Mendes (1992), como o principal de todos na cidade, em que finalmente houve a consolidação do processo.

Na década de 1990 nota-se a aprovação de vários loteamentos na cidade, ocupando vazios demográficos, principalmente a sudoeste, como havia sido apontado na década anterior.

A década de 2000 transparece uma urbanização já consolidada, ainda mais quando se compara o projeto inicial de Jorge Macedo Vieira com a malha urbana presenciada atualmente na cidade.

Durante o desenvolvimento da pesquisa constatou-se que a expansão da urbanização, o crescimento da malha urbana associada com o aumento populacional na cidade de Maringá, necessitou espaços, para que todas as construções fossem realizadas para o desenvolvimento da cidade. Essa urbanização acelerada começou a envolver as Unidades de Conservação da cidade em todas as direções e os primeiros processos de degradação ambiental começaram a surgir.

Concluiu-se, que até o ano de 1970, a urbanização ainda não tinha atingido as imediações do Parque Municipal do Cinquentenário, e neste ano, observou-se por meio das imagens e da técnica da análise multitemporal, uma degradação incipiente, provocada pelo uso e ocupação rurais até então. A degradação até este ano se situava nas áreas localizadas fora da unidade de conservação, sendo as principais o desmatamento da mata ciliar que acompanhava o córrego Mandacaru e o desgaste dos solos no entorno.

Verificou-se que a expansão urbana após o ano de 1970, cresceu de forma rápida na cidade de Maringá, sendo o período de maior crescimento da cidade, atingindo pela primeira vez as imediações norte do Parque Municipal do Cinquentenário, fazendo com que surgissem os primeiros sinais de degradação ambiental, que foram observados na Unidade de Conservação.

Os principais problemas ambientais, verificados nas áreas verdes protegidas pelo município, coincidem com a aproximação da urbanização no entorno deles, em suas áreas limítrofes.

Diante dos dados de degradação apresentados, comprovou-se a hipótese proposta no início desta pesquisa, de que o fator mais agravante relacionado à degradação ambiental, no caso das áreas protegidas da cidade, de fato foi à rápida expansão da malha urbana em seu entorno.

A caracterização da população de Maringá aqui realizada foi essencial para compreender as mudanças que aconteceram na área urbana da cidade, processo este que provocou significativas mudanças e alteração dos recursos naturais das áreas verdes do município. 
O aumento da população exigiu por parte do Poder Público, diversas incorporações de serviços, para receber tal contingente populacional, ou seja, equipamentos e obras de infraestrutura que também alteraram a paisagem natural e causaram diversos danos as unidades de conservação do município, como o Parque Municipal do Cinquentenário.

Resumindo, de forma breve, o que é notório e mais importante analisar por meio da exposição de todos esses dados, é uma grande e significativa mudança nas características da população do município, que era predominantemente rural passando a ser predominantemente urbana, com um crescimento acentuado e rápido, que afetou totalmente as áreas verdes do município de forma negativa, pois, apresentam problemas ambientais até hoje, problemas, que foram provocados e originados neste período de intensa urbanização da cidade, heranças negativas de um crescimento que podem ser evidenciadas nas áreas verdes até os dias atuais.

Dentro desse ponto de vista, é possível destacar que a cidade inicialmente planejada por Jorge Macedo Vieira, foi projetada para atingir 200.000 habitantes em 50 anos, uma meta difícil para qualquer cidade, mas que mesmo com esta ambição, o crescimento se configurou tão rápido, que em apenas 50 anos essa meta já seria atingida e ultrapassada durante a década de 1980, atualmente este número já quase que duplicou a meta estabelecida na fundação do município.

Enfim, concluiu-se também, que a metodologia aplicada da análise multitemporal, se mostrou eficiente quanto às avaliações temporais ambientais, se tornando uma ferramenta útil para um futuro plano de gestão ambiental dos órgãos governamentais responsáveis.

\section{REFERÊNCIAS}

ANDRADE, C. R. M. de; CORDOVIL, F. C. S. A cidade de Maringá, PR. O plano inicial e as "requalificações urbanas". Revista Electrónica de Geografía y Ciencias Sociales, Barcelona: Universidad de Barcelona, v. 12, n. 270, 2008.

BRASIL. Lei 9.985, de 18 de Julho 2000. Institui Sistema Nacional de Unidades de Conservação da Natureza. 2000. Disponível em: <http://www.planalto.gov.br/ccivil_03/LEIS/L9985.htm> Acesso em: 01/09/2015

ENDLICH, A. M. Maringá e a rede urbana regional: resgate histórico-geográfico. Boletim de geografia, Maringá v.17, n.1, p. 1-21, 1999.

INSTITUTO BRASILEIRO DE GEOGRAFIA E ESTATÍSTICA - IBGE. Censo Demográfico de 2010. Disponível em: 〈http://cidades.ibge.gov.br/painel/painel.php?codmun=411520> Acesso em: 01/09/2015.

IPEA/IBGE/UNICAMP/IPARDES. Caracterização e tendências da rede urbana do Brasil redes urbanas regionais: Sul. $1^{\text {a }}$ ed. Brasília: Globaltec Produções Gráficas. 2002. 266 p. 
JÚNIOR, J. S. B.; ALMEIDA, A. S. Análise multitemporal com a utilização da técnica de sensoriamento remoto e geoprocessamento no município de Bonito - Pará. In: SIMPÓSIO BRASILEIRO DE CIÊNCIAS GEODÉSICAS E TECNOLOGIAS DA GEOINFORMAÇÃO. 3. 2010, Recife - PE. Anais... Recife - PE, 2010, p. 1 - 7. Disponível em: <https://www.ufpe.br/cgtg/SIMGEOIII/IIISIMGEO_CD/artigos/CartografiaeSIG/SIG/A_71.pdf> Acesso em: 01/09/2015.

KERKHOFF, J. A. A política ambiental de Maringá como instrumento de desenvolvimento sustentável: Uma análise a partir da legislação ambiental municipal. 2010, 319f. Dissertação (Mestrado em Geografia), Centro de Ciências Humanas Letras e Artes, Universidade Estadual de Maringá, Maringá, PR. 2010.

LUZ, F.. O Fenômeno Urbano numa Zona Pioneira: Maringá. 1ª ed. Maringá, PR: Prefeitura Municipal de Maringá, 1997. 215 p.

MACHADO, J. R.; MENDES, C. O processo de verticalização do centro de Maringá - PR. Revista Investigaciones Geográficas, Cidade do México - México, UNAM, v. 1, n.52, p. 53-71, 2003.

MENDES, C. M. A verticalização, um dos reflexos do processo da metrópole em formação: Maringá, PR. Boletim da geografia, Universidade Estadual de Maringá (UEM). v. 10 - n. 1, p. 51 $-60,1992$.

MENDES, C. M. Uma metrópole em formação, Maringá - Paraná - Brasil. 2013. 9 f. Relatório de pesquisa. Departamento de Geografia, Universidade Estadual de Maringá, Maringá. Disponível em:<http://observatoriogeograficoamericalatina.org.mx/egal4/Geografiasocioeconomica/Geografia urbana/05.pdf> Acesso em: 01/09/2015.

MENEGUETTI, K. S. Cidade-jardim, cidade sustentável: a estrutura ecológica e urbana e a cidade de Maringá. $1^{a}$ ed. Maringá: Eduem, 2009, 206 f.

NETTO, L. G.; SANT’ANA, L. Uso e ocupação do solo no Ribeirão Maringá -PR. In: SIMPÓSIO DE ESTUDOS URBANOS. 1. 2001, Campo Mourão. Anais... Campo Mourão: SEURB, 2011, p. 1 -15 .

PREFEITURA MUNICIPAL DE MARINGÁ. Dados adquiridos pelo autor relacionados à expansão urbana de Maringá, 2010.

PREFEITURA MUNICIPAL DE MARINGÁ. Plano Municipal de Saneamento Básico Módulo Limpeza e Manejo de Resíduos Sólidos - PMSB - Maringá. Maringá: PMM, 2011, 237p. Disponível em: 〈http://www.maringa.pr.gov.br/saneamento/pmsb3.pdf >Acesso em: 01/09/2015.

REMOLLI, J. A. Praças e qualidade espacial: plano piloto da cidade de Maringá, Paraná. 2010. 144 f. Dissertação (Mestrado em Geografia), Centro de Ciências Humanas Letras e Artes, Universidade Estadual de Maringá, Maringá, PR. 2010.

RESCHILIAN, P. R.; UEHARA, A. Y. Desafios a questão metropolitana: O processo de organização do espaço urbano e regional de Maringá. Revista Oculum Ensaios, Campinas, v. 9, n. 15 , p. $76-87,2012$.

RODRIGUES, A. L. Características do processo de urbanização de Maringá, PR: uma cidade de “porte médio”. Revista Cadernos Metrópole, São Paulo, n. 12, p. 95-121, 2004 (a). 
RODRIGUES, A. L. A pobreza anda ao lado: Segregação sócio espacial na região metropolitana de Maringá. 2004. 258 f. Tese (Doutorado em Ciências Sociais), Pontifícia Universidade Católica de São Paulo, São Paulo, SP. 2004 (b).

SOARES, F. S.; ALVES, F. Análise multitemporal do desenvolvimento urbano do Distrito Federal. In: ENCONTRO NACIONAL DE ESTUDOS POPULACIONAIS. 14. 2006, Caxambu. Anais... Caxambú: ENEP, 2006. P. 1 - 15.

TEODORO, P. H. M.; AMORIM, M. C. C. T. Os caminhos das águas urbanas e seus traços em Maringá/PR. Presidente Prudente, Revista Formação, n. 17, v. 1, p. 35-55, 2009.

TORRES, D. R. Análise multitemporal do uso da terra e cobertura florestal com dados dos satélites Landsat e Alos. 2011. 96 f. Dissertação (Mestrado em Engenharia Florestal). Centro de Ciências Rurais, Universidade Federal de Santa Maria, Santa Maria. 2011.

UEHARA, A. Y. Um modelo de cidade jardim à metropolização: evidências do urbanismo à brasileira na região norte do Paraná. 2012. 101 f. Dissertação (Mestrado em Planejamento Urbano e Regional) Instituto de Pesquisa e desenvolvimento, Universidade do Vale do Paraíba, São José dos Campos, SP. 2012.

VERCEZI, J. T. Gênese e evolução da região metropolitana de Maringá. 2001. $178 \mathrm{f}$. Dissertação (Mestrado em Geografia) Universidade Estadual Paulista Faculdades de Ciências e Tecnologia, Presidente Prudente, SP. 2001. 